\title{
Organik Tarım Ürünlerinde Pazarlama Karması (4P) ve Bu Bağlamda Önemli Kavramlar
}

Öz

Tüketicilerin bilişsel yapılarını etkilemede örgütlerin önemli bir aracı olan pazarlama karmasının (4P), tüketicileri organik ürünler satın almaya yöneltme sürecinde etkin kullanımı, örgütlerin rekabetçi kalmalarında önemli bir rol oynayabilir. Bu çalışmada, organik ürün sektörüne yönelik her pazarlama karması elemanının içeriğinde önemli olabilecek kavramlara literatür üzerinden keşifsel bir bakış açısı ile yer verilmiştir. Pazarlamaya ilişkin çoğu tanımda, "değer yaratma" sözcüğü sıklıkla kullanılmaktadır. Pazarlama karması elemanlarının uygulanması noktasında müşteri değerine yönelik ele alınan kavramlar (bilgilendirme, eğitim, alg1, motivasyon, güven, evrenselcilik vb.) önemli olup organik ürün pazarında strateji geliştirmek isteyen üreticiler ve örgütlere yönelik bir yol haritası niteliği de taşımaktadır. Genel bir bakış açısıyla ele alınan, “organik ürün sektöründe pazarlama karması”na değinen az sayıda çalışma vardır. Bu nedenle, her karma elemanı bağlamında önemli olabilecek kavramlara değinerek, üretici ya da örgütlenmelerin tutundurma faaliyetlerinde öne çıkaracakları kavramları ortaya koymaya çalışmak, literatüre en azından bir teorik inceleme açısından katkı sağlayabilecektir. Çalışmanın özgünlüğü ve önemi buradan kaynaklanmaktadır.

Anahtar Kelimeler: Organik ürün, organik ürün pazarlaması, pazarlama karması.

\section{Marketing Mix (4P) in Organic Agricultural Products and Important Concepts in This Context}

\begin{abstract}
Effective use of the marketing mix (4P), which is an important instrument of organizations in influencing the cognitive structure of consumers and providing distinctive reasons for buying organic products, would play an important role for organizations to remain competitive. In this study, the concepts that may be important in the content of each marketing mix element for the organic product sector are presented with an exploratory perspective through the literature. In most definitions of marketing, the word "value creation" is often used. The concepts addressed to customer value (information, education, perception, motivation, trust, universalism, etc.) are important concepts in the implementation of the marketing mix elements and they are also a road map for producers and organizations that want to develop strategies in the organic product market. From a general point of view, there are few studies that address the "marketing mix in the organic product sector". Therefore, by addressing the concepts that may be important in the context of each mixed element, trying to put forward the concepts that will be highlighted by the producers or organizations in promotion activities may contribute to the literature in terms of at least one theoretical examination. The originality and importance of the study stems from this.
\end{abstract}

Keywords: Organic product, organic product marketing, marketing mix.

*ORCID Dr., ykyurek@hotmail.com 


\section{Extended Abstract}

\section{Introduction and Research Purpose}

The effective use of the marketing mix (4P), which is an important tool of organizations in influencing consumers' cognitive structures, in the process of directing consumers to purchase organic products, can play an important role in keeping organizations competitive. The purpose of the study is to reveal the concepts that may be important in the content of each marketing mix element for the organic product sector are presented with an exploratory perspective through the literature.

\section{Literature Review}

In most definitions of marketing, the word "creating value" is often used in most marketing definitions. There are few studies addressing the "marketing mix" in the organic product industry, which are handled from a general perspective. Therefore, trying to reveal the concepts that producers or organizations will put forward in promotion activities by mentioning the concepts that may be important in the context of each mixed element may contribute to the literature in terms of at least one theoretical study. The originality and importance of the study stems from this.

\section{Methodology}

The methodology of the study is literature review. In this regard, in the research, concepts that may affect consumers' perceptions and purchasing behaviours regarding organic products, beyond the product, price, promotion and distribution activities, which are traditional 4P focuses in organic products, were investigated.

\section{Results and Conclusions}

The concepts (information, education, perception, motivation, trust, universalism, etc.) addressed to customer value at the point of application of the marketing mix elements are important and also constitute a road map for producers and organizations who want to develop a strategy in the organic product market. 


\section{Giriş}

Organik ürünler, tüketicilerin sağlık konusundaki inançları temelinde motive olarak satın aldığı ürün grupları olduğu şeklinde tanımlanabilir. Besin değeri, lezzet, tazelik, ürünün görünümü ile sunum şekli gibi tüketicilerin duyusal özelliklerine hitap eden kavramların yanı sıra gıda güvenliği, insan sağlığı ve çevresel sorunlar gibi kavramların da etkisiyle, özellikle gelişmiş ekonomilerdeki satın alma gücünün sağladığı ürünlerde "özellik arayışı” davranışı da göz önüne alındığında, organik gıda, tüketicilerinin satın alma tercihleri etkilenebilmektedir.

Organik tarımdan evvel, örgütlerin ve üreticilerin artan dünya nüfusunun gıda gereksinimlerini karşılamanın yanında, verimliliği ve kazançlarını arttırmaya yönelik arayışları neticesinde, birim alandan en fazla verimi en kısa sürede alma rekabeti entansif tarım ${ }^{1}$ yöntemlerini meydana çıkarmıştır. Bu tarihsel süreç içerisinde, kimyasal gübre ve ilaçlar denenmiş, kaliteli tohumluğa önem verilemeye başlanıp yüksek verimli çeşitler hedeflenmiştir. Sürekli artan dünya nüfusunun tüketim talebi de organik tarımsal ürün arzını baskılamış, ekosisteme zarar vermiş ve neticede organik tarım istenen düzeyde gelişememiştir. Ülkemizde bu sektöre yönelik sayılabilecek olumsuzluklardan bazıları; yanlış ya da eksik bilgi, gelir düzeyi, ürünlerin aşırı pahalı olması, pazarlama alt yapısındaki olumsuzluklar ve tüketici bilincinin eksikliğidir. Bütün bu olumsuzluklar organik tarım ürünlerinin daha geniş bir kesime hitap etmesini engellemektedir (Kaya 2010; akt. Eti, 2014: 30). Bu bağlamda, Adam Smith (2017: 9)'in dediği gibi en varlıklı uluslar gerçekten de sanayide olduğu kadar tarımda da tüm diğer komşularından üstündürler. Gelişmekte olan ülkelerde ise organik tarıma geçişin en önemli nedeni, gelişmiş ülkelerde oluşan pazar fırsatlarıdır (Kurt, 2006: 12).

Organik tarım üretimi yapan ülkeler tüm dünyada genellikle üretime geçişte ülkelerinin geleneksel ürünlerinden başlamayı tercih etmişlerdir (Marangoz, 2008: 30). Örneğin; Hindistan'da çay, Danimarka'da süt ve ürünleri, Arjantin'de et ve mamulleri, Orta Amerika ve Afrika ülkelerinde muz, Tunus’ta hurma, zeytinyağı, Türkiye'de kurutulmuş ve sert kabuklu meyveler, organik olarak üretilen ilk ürünlerdir (Usal, 2006: 18). Meyve ve sebzeler organik gida konusunun ana odağıdır (Padel ve Foster, 2005: 621). 1990'lar dan beri, AB ülkelerinde organik tarımın gelişmesi, mali sübvansiyonlar aracılığıyla desteklenmiştir. Ekolojik tarımın gelişimi özellikle ABD, Avrupa Birliği ve Japonya'da talebin artması ile birlikte bir hayli hareket kazanmıştır (Defrancesco ve Rossetto, 2007).

Günümüzde tüketicilerin çevresel konulara ilişkin artan bilinçlerinin yanı sıra eğitim ve gelir seviyelerinin de artmasına paralel sağlıklı gıda tüketimine yönelmeleri, doğal olarak organik gıda pazarına olan ilginin ve pazarın hacminin artmasına yol açmış ve alternatif olarak yeni bir üretim yöntemi olan organik tarım ortaya çıkmıştır (Çelik ve Bilgiç, 2003: 12). Bu noktada araştırma, örgütlerin pazarlama karması elemanlarının organik ürünlere yönelik uygulanmasında, tüketicilerin bu ürünlere ilişkin algıları ve satın alma davranışlarını etkileyen hususlar ele alınmış ve geleneksel 4P odakları olan ürün, fiyat, tutundurma ve dağıtım faaliyetlerinden farklılaşan ve öne çıkan kavramlar irdelenmiştir.

\section{Organik Tarım ve Yeşil Tüketim Kavramı}

Bir sertifikasyon süreci ile kontrol edilen üretime “Organik Üretim” ve bu yolla elde edilen ürünlere de “Organik Ürün” denilmektedir. Organik/Ekolojik Tarım; toprağın verimliliğini, bitki ve hayvan sağlığını koruyan ve geliştiren biyolojik proseslere dayanan, ekolojik olarak

\footnotetext{
${ }^{1}$ Entansif tarım: Bir araziden bir yılda birden çok ürün elde edilen, nadassız tarım veya yoğun tarım olarak da adlandırılan entansif tarım, teknolojik gelişmelere paralel olarak yoğun makine kullanımı yapılan ve tarım topraklarına aşırı gübreleme ve ilaçlama yapılan tarım yöntemidir.
} 
sürdürülebilir tarım sistemini ifade etmektedir (Ersun ve Arslan, 2010: 24). Organik tarım ekosistemin çok iyi tanınmasını ve üretimle ilgili tüm tekniklerin bilinmesini gerektiren bir sistemdir. Bu yönü ile esasında organik tarım sistemi, yüksek kalite elde etmeyi de amaçlayan bir tarım sistemidir.

Tüketiciler her gün onlarca farklı gıda katkı maddesi ve gıdalara bulaşan diğer kimyasal maddelerin etkisine maruz kalmaktadır (Erkmen, 2010: 222). Organik gidalar daha az zararlı katkı maddeleri içerir ve konvansiyonel gıdalardan daha fazla birincil (örneğin, $\mathrm{C}$ vitamini, kuru madde, mineraller) ve ikincil besinleri (bitkisel gidaları (phyto-nutrients)'leri) de kapsar. Başka bir deyişle, organik gıdalar en azından ek gıda zehirlenmesi riski taşımamaktadır (Heaton, 2001; akt. Chen, 2007: 1008).

Organik tarım konvansiyonel/geleneksel ${ }^{2}$ tarıma alternatif olarak düşünülerek çıkarılmış ve 1910 yilında Albert Howard'ın "Tarımsal Vasiyetnamesi” ve 1924 yılında Dr. Rudolf Steiner'in "Biyodinamik Tarım Yöntemi” çalışmaları, birçok Avrupa ülkesinde bu konuda duyarlı üretici ve tüketicilerin bir araya gelmesine ve organik tarım çalışmalarına başlamalarına yol açmıştır. Medyanın artan ilgisi, yapılan bilimsel çalışmalar neticesinde de çok yönlü tanımlanan "yeşil tüketim” (green consumerism) kavramı ortaya çıkmıştır. Yeşil tüketim; çevrenin korunması, kirliliğin en aza indirilmesi, yenilenemeyen enerjilerin sorumlu kullanımı ve türlerin korunması ile hayvan sağlı̆̆ını içeren bir kavramdır (Chryssides ve Kaler, 1993). Pettie (1992)'e göre bu kavram, sosyal ve çevresel kriterlere dayanan bir satın alma sürecidir. “Etik” veya "yeşil”" (green) tüketiciler de sürekli olarak ürün veya şirket bilgileri arar ve çeşitli çevresel ve/veya toplumsal etkileri satın alma davranışlarına entegre etmeye çalışırlar (McEachern ve McClean, 2002: 85). Sonuçta yeşil tüketimi tanımlayan kavramlar organik tarımın ilke ve amaçları içerisinde yer almaktadır.

\section{Organik Tarımın İlke, Amaç ve Değerleri}

Son yıllarda, özellikle tarım alanındaki yeni üretim tekniklerinin özellikle insan sağlı̆̆ının üzerindeki olumsuz etkileri, tüketici tercihlerini değiştirmiş, alışverişte daha doğal gıdaların tercih edilmesine vesile olmuştur. Tüketici talebinde yaşanan bu değişim, dikkatleri organik gıda üzerine çekmiş, özellikle tüketici açısından incelenmesini gerekli kılmıştır (Canarslan ve Uz, 2019: 457).

Organik tarımın başlıca üç ilkesi bulunmaktadır. Bunlar; doğa ile uyumlu üretim, kapalı sistem (kendine yeterli tarım) ve sürdürülebilirliktir (toprağın iyileştirilmesi ve içindeki organizmaların korunması) (Demirer, 2002: 3). Organik tarımda temel amaç, insanın kullandığ1 her türlü gıda ve besin maddeleriyle, barınma ve giyinme maddelerinin insan sağlığına zarar vermeyecek ya da en az zarar verecek şekilde ve devamlı olarak üretilmesidir (Gündüz ve Kaya, 2007: 315). Bu amaca ek olarak; üretici ve tüketicilerin bilinçlendirilmesi, organik üretimin artırılması ve çeşitlendirilmesi, iç ve dış pazar araştırmaları yapılarak üretimin yönlendirilmesi ve geliştirilmesi, tüm organik ürünler için ortak bir logo ve gerçekçi veri tabanı oluşturma (organik üretim faaliyetlerinin planlanabilmesi) şeklinde özetlenebilir (Aksoy, 2001: 121). Bir maliyet unsuru olan enerji kaynaklarının optimum kullanımı noktasında ise güneş enerjisi ve rüzgâr enerjisi gibi doğal enerji kaynakları olabildiğince tercih edilmelidir (Altındişli ve İlter, 2002: 21).

\footnotetext{
${ }^{2}$ Konvansiyonel tarım: Ürünü garanti altına almak için gittikçe artan oranda sentetik mineral gübreler ve sentetik kimyasal tarım ilaçları kullanılan ve amacı birim alandan en yüksek oranda ürün elde etmek olan bir tarım yöntemidir.
} 
Organik tarım “doğal tarım” ya da "gübresiz ve ilaçsız tarım” demek değildir. Organik Tarım; sürdürülebilir bir eko-sistem, güvenli gıda, sağlıklı beslenme, sosyal adalet ve daha iyi çevresel yaşam şartları ile sonuçlanan bir süreçler dizisine dayalı, bütünsel bir sistem yaklaşımıdır. Bu nedenle organik üretim sadece belirli girdileri kapsayan veya dışlayan bir üretim sistemi olmanın ötesinde bir anlam ifade etmektedir (Kırımhan, 2005: 37).

Değerler tutum ve davranışları yönlendiren veya belirleyen standartlardır ve bireylerin bilişsel sistemine daha merkezi şekilde bağlıdır (Rokeach, 1973: 737). Tüketicilerin organik ürün tüketimiyle ilişkili temel değerleri; güvenlik, hedonizm, dürtü, evrenselcilik, hayırseverlik, kişisel gelişim, uyum ve güç gibi temel değerlerdir (Aertsens vd., 2009b: 11431145). Bu değerler, az verim alınan organik ürünlere yönelik pazarlama karması stratejileri oluşturulurken örgütlerin göz önünde bulundurması gereken faktörler olarak da değerlendirilebilir. Zira, organik ürünlere ilişkin ana nedenlerden biri algılanan değer eksikliğidir (Makatouni, 2002: 346).

\section{Pazarlama Karması Kavramı ve Modern Tüketici Pazarlaması}

Pazarlama karması kavramı Borden tarafindan, 1950'lerde ortaya koyulmuş ve farklı rekabet araçları karmasından oluşan bu kavram 4P (price, place, promotion, product: fiyat, dağıtım, tutundurma, ürün) olarak tanımlanmıştır. Bu araştırma kapsamına "hizmet pazarlaması" dahil edilmediğinden sadece ürünlere yönelik olarak pazarlama karması elemanları ele alınmıştır.

Örgütler 4P elemanlarını şekillendirirken iç ve dış çevre faktörlerini dikkatle ele almalıdırlar. Dış çevre faktörleri olarak ele alınan makro (sosyo-demografik, ekonomik, kültürel, politik, hukuki, rekabet ve teknolojik) çevre faktörleri, organik gıda satın alım kararlarında etkisi olan faktörlerdir. Örneğin gelir ve organik ürün bilgisi (organic knowledge), organik gıda ürünleri satın alma kararını olumlu yönde etkilemektedir (Gracia ve Magistris, 2007: 439). Mikro çevre faktörleri (pazar, üretim araçları sahipleri, aracı kuruluşlar), iç çevre faktörleri (örgütün imkân ve kabiliyetleri, finansman, üretim, personel, araştırma-geliştirme, kuruluş yeri, imaj) ve 4P elemanları (ürün, fiyat, tutundurma, dağıtım) eş zamanlı olarak örgütlerin kontrol edebildiği değişkenler olarak ele alınmaktadır. Bu değişkenler de organik ürün tüketimini etkiler. Örneğin, Arjantin’deki organik ürünlerin iç piyasadaki azlığg ve yüksek fiyatlar, organik ürünlerin iç tüketim artışı noktasında aşılması gereken en büyük engeller olarak tanımlanmaktadır. (Rodriguez, Lacaze ve Lupin, 2008: 9).

4P kapsamında örgütler, ürettikleri ürünlere müşterilerinin ödemeye razı oldukları bedeli biçerler. Bu noktada örgütler "ürün”lerini müşterilerinin arzu ve ihtiyaçları doğrultusunda geliştirebilirler. Örgütlerin "fiyat" ile ilgili alabileceği kararlar; fiyatlandırma stratejileri, fiyat indirimleri ve kredilerdir. "Tutundurma” karması ise hedef pazara yönelik ürünler hakkında bilgi verilmesi ve müşterilerin örgütün ürünleri hakkında yeterli bilgiye sahip olup ürünleri satın almaya yönelmesi/yönlendirilmesi ile ilgilidir. Tutundurma stratejileri (itme, çekme), reklam, satış geliştirme ve halkla ilişkiler faaliyetleri pazarlama yöneticilerinin bu kapsamda başvurabileceği araçlar olarak sıralanabilir. Son karma elemanı olan "dağıtım” ürünlerin nihai tüketiciye ulaştırılması ile ilgili faaliyetleri içerir. Dağıtımın 4D prensibi (doğru yer, zaman, miktar ve müşteri) çerçevesinde gerçekleşmesi etkinlik ve verimlilik noktasında önemlidir. Sonuçta bu iç ve dış çevre faktörleri örgütlerin yaşadıkları ekolojiyi oluştururlar. Bu ekoloji genellikle bir denge içerisinde işleyişine devam etse de zaman içerisinde bu ekolojiyi oluşturan değişkenler dramatik değişimler sergiler ve örgütlerin $4 \mathrm{P}$ stratejilerini revize etmeye zorlar.

Yeni tüketici geleneksel pazarlama uyaranlarına daha az tepki veren tüketiciler olarak tanımlanmaktadır (Constantinides, 2006: 412). Çalışmanın ilerleyen bölümlerinde ele alınan 
pazarlama karması odakları (geleneksel ve organik ürün) arasındaki farklılıklar, örgütlerin yaratmak istedikleri tüketici tepkileri noktasında dikkat etmeleri gereken kavramlar sunmaktadır. Daha fazla araştırmacı, modern tüketicinin farklı olduğu görüşünü (talepkâr, bireysel, katılımcı, bağımsız, daha iyi bilgilendirilmiş, daha eleştirel ve sosyal meselelere daha ilgili) paylaşmakta ve örgütlerin sadece kâr mantığına uygun olarak faaliyet gösteremeyeceğini ileri sürmektedir (Capon ve Hulbert, 2000; Boccia ve Sarnacchiaro, 2018). Yukarıda bahsi geçen talepkâr, iyi bilgilendirilmiş ve eleştirel tüketici davranışları ve özellikleri, örgütlerin pazarlama faaliyetleri içerisinde ihtiyaç duyduğu ve kullanabileceği faktörler olabileceği de görülecektir. Çünkü ekolojik pazar bölümüne ait tüketiciler, kendilerini gerçekleştirmeleri ile karakterize edilen tüketicilerdir ve bu insanlar her zaman kendini geliştirmeye inanır ve zorlayıcı olan eylemde bulunur (Paul ve Rana, 2012: 413). Ayrıca tüketicilerin değişiminin altında yatan diğer bir faktör, tüketicinin kişisel bilgi işlem gücünün olması (Constantinides, 2006: 413) ve tüketicilerin internet vasıtası ile veri tabanlarına ve satıcılara ulaşması ile sosyal meseleler hakkında hızlı bilgi alabilmesidir. Sonuçta dijitalleşme, internetten direkt satış yapan organik ürün üreticileri için her geçen gün ivme kazanabilecekleri bir avantaj olarak düşünülebilir.

\section{Organik Gıdaya Yönelik Pazar Bölümlendirmesi}

Günümüzde rakip örgütlenmelerin başarısı, stratejik düşünme ve analizler neticesinde karar verilen stratejiyi güncel tutarak uygulayabilme anlayışının gücüne bağlıdır. $\mathrm{Bu}$ bağlamda örgütler, ellerindeki sınırlı kaynakları, doğru pazara ve müşteriye yönlendirerek pazarlama etkinliklerine cevap verecek nitelikte bölümlere/müşterilere ayırmaları gerekmektedir. Hedef kitlenin genel olarak kimlerden oluştuğu, bu kişilerin hangi tüketim alışkanlıklarını gösterdikleri, nüfus içerisindeki oranı ve toplam gelirden aldıkları paylar, ikamet yerleri gibi faktörler göz önüne alınarak bölümlendirme stratejileri ilerletilmelidir. Organik ürün sektörü çeşitli nedenlerle tüketiciler açısından küçük pazar bölümlerine ayrılmıştır. Bu nedenlerden bazıları giderek artan rekabet, mal ve hizmetlerin çeşitlenmesi, kişisel gelirdeki değişim ve de gıda perakendeciliği sektöründeki hızlı büyüme ve gelişmedir (Eti, 2014: 47). Ayrıca organik ürünlere ilişkin daha önce yapılan çalışmalar, bir organik ürün için ödeme istekliliğinin, olağan sosyo-ekonomik değişkenlerden ziyade, bireysel yaşam biçimlerinden (işlenmemiş ve vejeteryan gida seçimi, düzenli egzersiz vb.) etkilenebileceğini göstermiştir (Hartman, 1997, akt. Klonsky, 2000: 233).

\subsection{Coğrafi Bölümlendirme}

Organik tarım ürünleri pazarlanmasında oldukça etkili olabilen bir bölümlendirme yöntemidir. Özellikle kentsel bölgelere öncelik verilerek, pazar çeşitli bölgelere ayrılmaktadır. Gıda ulaşılabilirliği ve mevsimsellik, pazarlama faaliyetlerini etkiler ve uygun perakende satış yerlerinin kurulmasını zorlaştırır. Organik üretimin önündeki ana engel de perakende gıda piyasalarında organik ürünlerin satılmasındaki zorluk gibi görünmektedir (Gil, 2000: 208).

Türkiye'de organik ürünlerin en fazla tüketildiği pazarlar nüfusun en kalabalık olduğu İstanbul, Ankara, İzmir, Adana, Konya, Bursa gibi büyük şehirlerde, gelir seviyesi ve entelektüel düzeyi yüksek olan kişilerin yaşadığı yerler olduğu söylenebilir. Coğrafi bağlamda, artan küreselleşme, eğitim ve gelir seviyeleri ile Orta ve Doğu Avrupa ülkelerinin tüketicileri, güvenli ve besleyici gida maddeleri talep etmektedir (Zakowska-Biemans, 2011; akt. Rana ve Paul, 2017: 159). Bunun yanında büyük turizm merkezleri, eko turizmin geliştiği bölgeler de organik pazarların geliştiği yerler olarak zikredilebilir (Ersun ve Arslan, 2010: 102-124). 
Dolayısı ile örgütler, organik ürünlere ilişkin bölümlendirme stratejileri ile ilgili değişkenleri aktif şekilde izleyerek güncel tutmalıdırlar.

\subsection{Tüketicinin Demografik Özellikleri}

Literatürde organik ürün alanların tipografisini geliştirmeye dönük çalışmalar yapılmıştır. Tüketicilerin organik ürün tercihlerinin demografik özelliklere bağlı olarak değişkenlik gösterdiği ortaya çıkarılmıştır (Sarıkaya, 2007: 122). Organik ürün pazarı tüketici özellikleri bakımından ikiye ayrılmaktadır. Birinci ve en büyük pazar sağlık pazarıdır. Bu pazardaki tüketiciler organik ürünleri geleneksel ürünlerden daha sağlıklı buldukları için satın almaktadırlar. İkinci gruptaki tüketiciler ise, organik ürünleri sosyal etkileri sebebiyle tercih eden tüketicilerdir. Temiz bir çevre, daha küçük ve zararsız tarım alanları ve yerel üretilmiş ürünler bu tüketici grubu için önemlidir (Knudson, 2007: 2).

Organik tarım ürünleri hedef pazar bölümleri; yüksek gelirli, eğitimli, 0-7 yaş arası çocukları olan, sağlığa ve çevreye önem veren, çalışan ve çoğunlukla bayan tüketicilerden oluşur (Kurt, 2006: 18). Özellikle gelir düzeyi yüksek ve orta yaş grubu tüketiciler, organik ürünlere yönelik talep yaratmada başlıca hedef pazarı oluşturmaktadır (Araslı ve Esen, 2008: 42).

Tüketicilerin eğitim seviyelerinin ve gelir düzeylerinin artmasıyla birlikte bilinçlenme ve organik ürünlere olan talep artış göstermektedir (Özcan, 2008; akt. K1lıç, 2014: 44). Yaş ve eğitim seviyesi yükseldikçe organik ürünlere yönelik bilgi düzeyinin arttığı ortaya çıkmıştır (Dalkıran, 2009: 156). Misra vd. (akt. Rodriguez, 2008: 2)'de eğitim ve taze organik ürün tüketimi arasında negatif bir korelasyon elde etmişlerdir. Tüketicilerin organik ürün kavramından haberdar olma durumu ile eğitim düzeyleri arasında bir ilişski olup olmadığ 1 arandığında, bu kavramdan haberdar olanların çoğunun lise ve üzerinde eğitime sahip olduğu görülmüştür (Ersun ve Arslan, 2010: 112). Alanyazın da kadınların organik gıda ürünleri ile erkeklerden daha çok ilgilendiği ve bu ürünleri daha sık satın aldığına yönelik bulgular görülmekle birlikte kadınlar, organik ürünlere karşı daha pozitif bir tutum sergilemektedir (Eti, 2014: 75).

Genç çalışan kadınlar ve orta yaşlı kadınlar organik ürünlerin temel alıcıları arasındadır (Padel ve Foster, 2005: 618). Mintel (2000)'in gerçekleştirdiği bir anket çalışmasının bulgularına göre, en genç ve en yaşlı yaş grupları sağlık ve diyet konuları üzerinde daha az durduğundan organik ürünlere en az ilgiyi gösteren gruplardır. Ayrıca organik sebzeyi satın alan en yaygın grubun ise 45-54 yaş grubu olduğu saptanmıştır. Diğer bir çalışmada tüketicilerin organik ürün satın alma davranışları ve tutumları açısından dört boyutun öne çıktığ1 bulunmuştur. Bunlar; sorumluluk, güven, değer ve fayda boyutlarıdır (Padel ve Foster, 2005: 608).

\subsection{Psikografik Bölümleme}

Bu bölümlendirme de tüketicilerin kişilikleri ve yaşam tarzları ağırlıklı olarak dikkate alınır ve organik tarım ürünlerini satın almaları için gerekli duygusal ve davranışsal bilgiler incelenir. Yapılan araştırmalar tüketicilerin organik ürünleri tercih etme nedenlerinin başında, sağlık problemleri ya da sağlıkla ilgili endişelerinin olmasını ve doğal çevreye karşı duyarlı olmalarının geldiğini göstermektedir (Magkos vd., 2006; Wier ve Calverly 2002).

Organik ürünlere ilişkin tüketici tercihleri konulu çalışmalarında "tüketicilerin niçin organik ürün satın aldıkları” sorusuna cevap olarak, tüketicilerin sağlık, çevre ve hayvan refahı 
gibi konulara yönelik kaygılarından dolayı organik ürün satın aldıkları bulgularına ulaşmışlardır. Ayrıca çeşitli anket çalışmalarında "kişisel sağlık" organik ürünleri satın almada güçlü motivasyon faktörü olarak varlığını sürdürmektedir (Padel ve Foster, 2005: 609). Magistris ve Gracia (2008)'de ağırlıkla bir diyet programı ve dengeli beslenme şeklini tercih eden tüketicilerin organik ürünlere yönelik daha olumlu tutumlar sergilediklerini bulgulamışlardır. Sonuçta yapılan pek çok araştırma göstermektedir ki tüketicilerin organik gıda satın almaya yönelmesindeki nedenler, algılanan sağlık ve beslenme faydalarıdır (Tirkeş, 2008).

Aşağıda Şekil 1'de gösterilen merdiven tekniğinde amaç, tüketicilerin organik gida alım kararlarının altında yatan temel motive edici değerleri gün yüzüne çıkarmaktır. Nitelik, sonuç ve değer şeklinde üç temel basamağa bölünmüş olan neden-sonuç zinciri yaklaşımında katkılar soyut ya da somut, sonuçlar fonksiyonel ya da psiko-sosyal ve değerlerin ise araçsal ya da nihai olabileceği görülmektedir.

Şekil 1: Neden Sonuç Zinciri Örneği
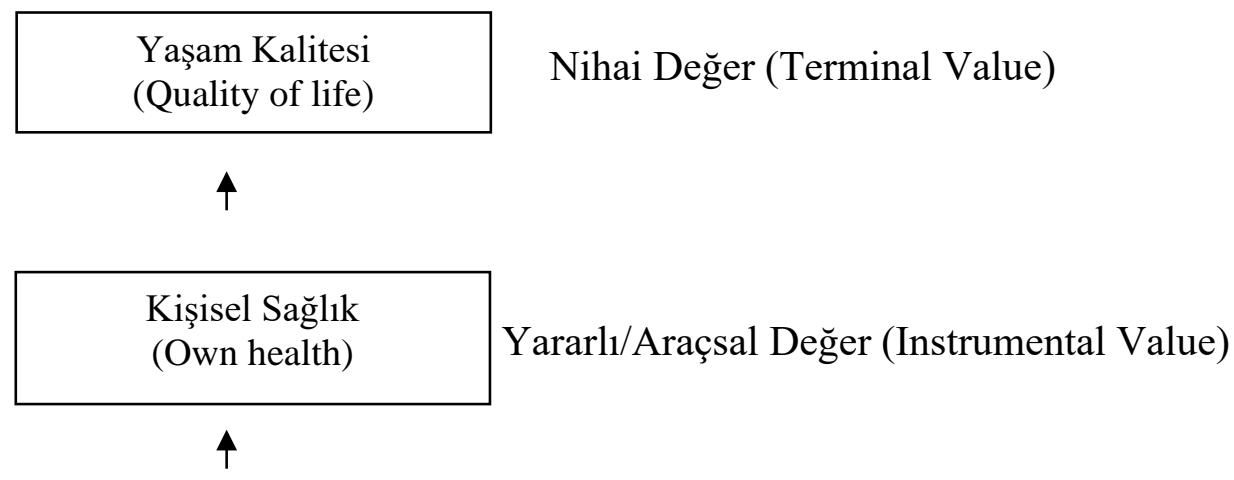

İyi Hissettirme (Makes me feel good) Psiko-sosyal Sonuçlar (Psycho-social consequence)

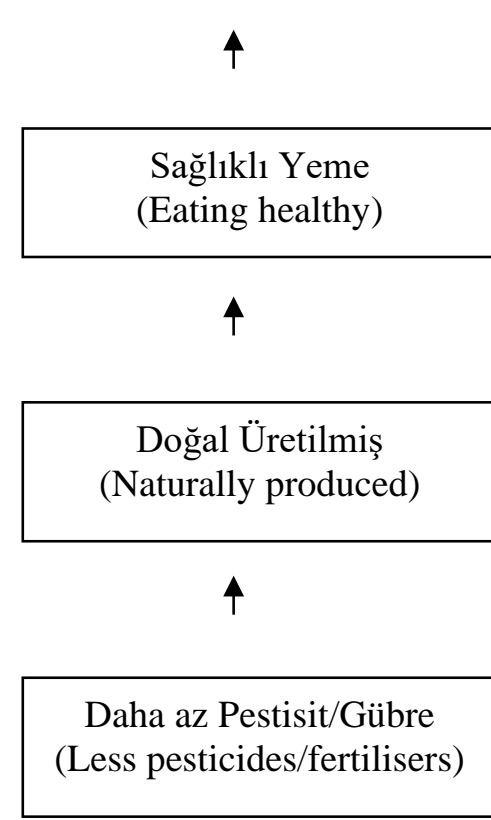
Fonksiyonel Sonuçlar (Functional consequence)

Kaynak: Zanoli (2004)'den uyarlanmıştır; akt. Padel, S., \& Foster, C. (2005). 
Yaşam kalitesi bireyin farkındalığı ile ilişkili bir kavramıdır. Kim ve Chung (2011), sağlık farkındalığının, tüketicilerin satın alma davranışlarını etkilemede en önemli faktör olduğunu dile getirmiş, sağlıkla ilgili farkındalığın düşük olduğu yerlerde de tüketici satın alma niyetinin düşük olduğu sonucuna ulaşmışlardır (akt. Singh ve Verma, 2017: 475). Tutumlar ve motivasyonlar satın alınan organik ürünün kategorisine göre değişiklik gösterebilir. Yukarıda Şekil 1 örgütlere, organik ürünlerin pazarlanmasında nihai tüketicilerin satın alma noktasında bilişsel yapılarını harekete geçirecek kavramlar sunmaktadır.

Organik tüketicilerin tercihlerinin, tutumlarının ve bilgilerinin daha iyi anlaşılması, konumlandırma, iletişim, fiyatlama, dağıtım ve tutundurma konusunda pazarlama yöneticilerine yardımcı olacak bilgiyi sağlayacak ve bu sayede organik ürün tercihleri ile kişisel ve psikografik özellikler arasındaki ilişkinin güçlendirilmesine yönelik faydalar sunan faaliyetler geliştirilebilecektir (Essoussi ve Zahaf, 2008:102). Neil Borden da "The concept of marketing mix" adlı eserinde örgütlerin, pazarlama karmasını geliştirme noktasında, tüketicilerin satın alma davranışını göz önünde bulundurması gerekliliğini vurgulamaktadır (Anderson ve Taylor, 1995: 2).

\subsection{Davranışsal Bölümleme}

Bu bölümleme çoğunlukla tüketicilerin hangi satın alma güdüsü ile hareket ettiğine göre bir ölçüt belirler. İnsanın yemek seçimi birçok etkinin karmaşık bir işlevidir (Furst vd., 1996). Bu etkiler/belirleyiciler, gıdanın duyusal yönleri (tat, koku, doku özellikleri) ile kombine olan gıda dış1 (bilişsel bilgi, fiziksel çevre, sosyal faktörler) faktörleri içerir (Bell ve Meiselman, 1995; Eertmans vd., 2001). Tutum, niyet ve davranış şeklinde ilerleyen "Planlı Davranış Teorisi" (PDT) genellikle gıda seçimi alanında ve daha yakın zamanda tüketicilerin organik gıda seçimini modellemek için uygulanmıştır (Saba ve Messina, 2003; Chen, 2007; Gracia ve Magistris, 2007).

PDT Temel olarak üç faktör tarafından belirlenir: Kişinin davranışa girme yönündeki tutumu (satın alma tutumu), davranış noktasında kişi tarafından hissedilen sosyal baskı derecesi (öznel norm) ve kontrol derecesi, davranışın kişisel olarak kontrol edilip edilemediği (yani algılanan davranışsal kontrol). Ayrıca algılanan davranış kontrolü, zaman, bulunabilirlik ve tanınma (etiketleme) gibi dış faktörlerin etkilerini de kapsar (Chen, 2007: 1009). Aşağıdaki Şekil 2'de planlı davranış teorisi temelinde “organik gıda tüketiminde kişisel belirleyiciler” ele alınmaktadır. 
Şekil 2: Organik Gida Tüketiminin Kişisel Belirleyicileri

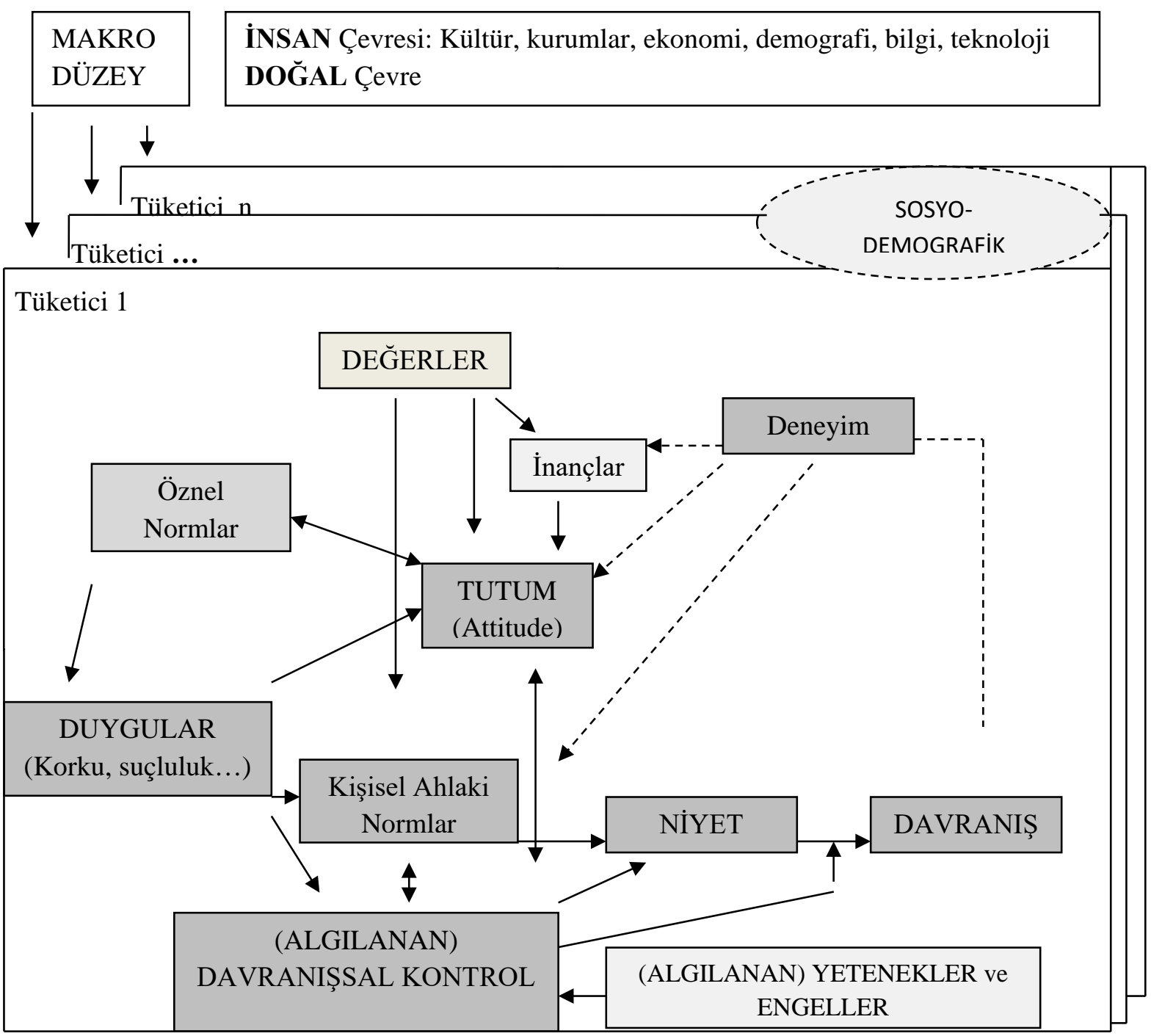

Kaynak: Aertsens, vd. (2009b).

Niyetler, planlı davranışın en iyi yordayıcısıdır (Bagozzi vd., 1989). Kişisel değerler ile davranış arasındaki görgül ilişki genellikle düşük (Brunso vd., 2004) olsa da değerler ve tutum arasındaki bağ, deneysel araştırmalarla desteklenir ve bu gıda (doğal veya organik) alımı için de geçerlidir (Goldsmith vd., 1997). Değerler, duyusal algıları, parasal düşünceleri, sağlık ve beslenme inançlarını, kilo kontrol kaygılarını, rahatlığı vb. içerir (Furst vd., 1996). Ben merkezci (egocentric) değerler organik gıda alımı için özgecil (altruistic) değerlerden daha güçlü motive edicilerdir (Johnston, 2008). Bireylerin organik gıda satın alma tutumlarında öznel ve ahlaki normlar da etkilidir. (Thøgersen, 2002; 2007). Neticede organik gida tüketimine yönelik tutumlar temel olarak, sonuçlara ilişkin inançlara dayanır (çevre için daha iyi, daha lezzetli, daha sağlıklı) ve organik ürün satın alımları, olumlu ve anlamlı şekilde davranışsal kontrol (algılanan) ile de ilişkilidir (Aertens vd., 2009b: 1156).

Çeşitli gıda korkularından kaynaklanan tüketici endişesi, gıda satın alma biçimlerini etkilemektedir. Ayrıca bilimsel bilgi'deki önemli boşluklar göz önünde alındığında, gıda içindeki doğal toksik maddeler, sentetik kimyasallar ve çevresel kirleticiler hususunda riskleri 
tartmak özellikle zordur. (Magkos vd., 2006: 23-45). Aşağıda Şekil 3'de tüketicilerin gıda ile ilişkili risklere karşı davranışlarını/tutumlarını gösteren bir süreç yer almaktadır.

Sekil 3: Gıda ile İlişkili Risklerde Tüketici Davranış1

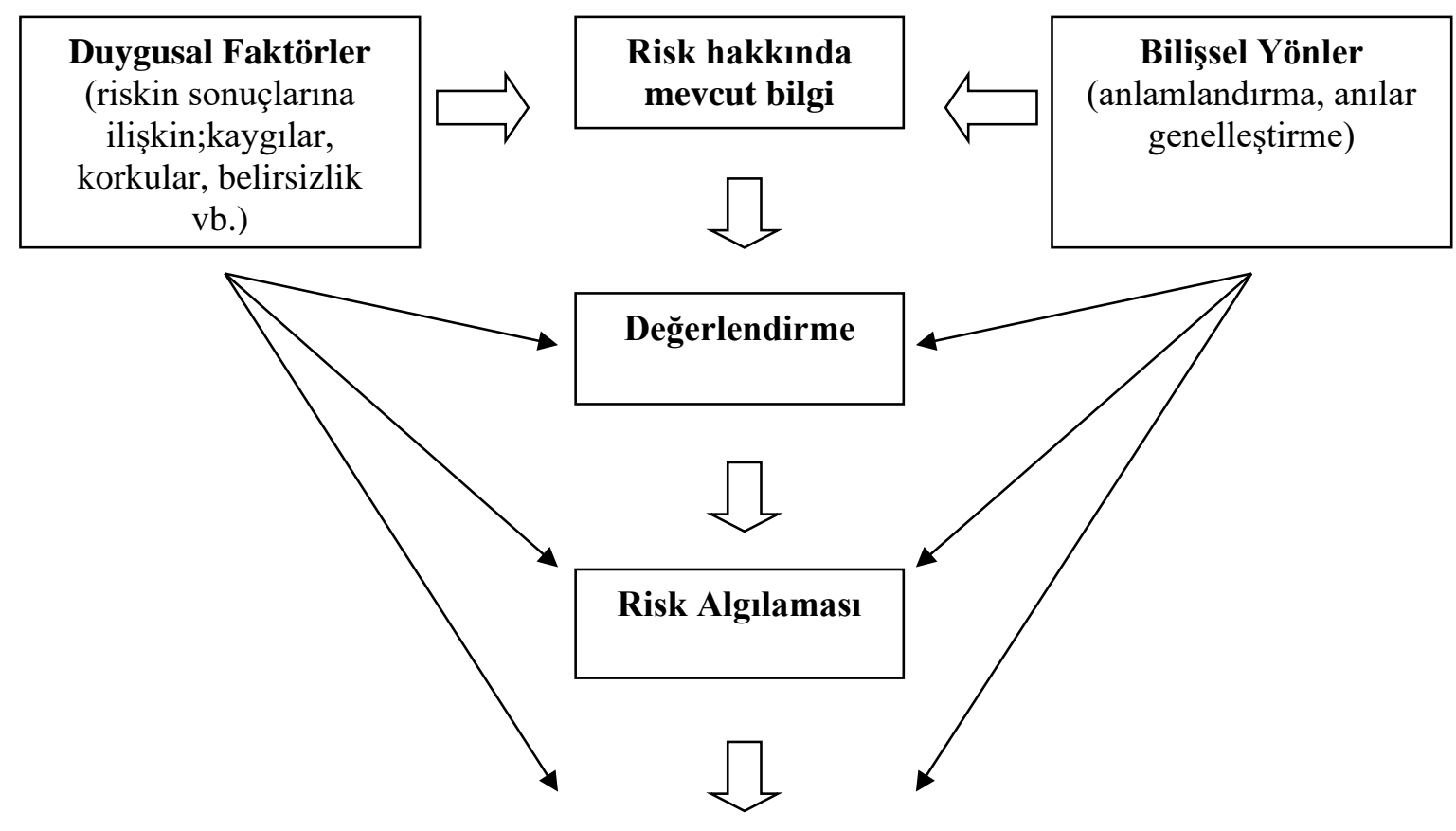

Tüketici

Davranışı

Kaynak: Magkos vd. (2006).

Şekil 3 yorumlandığında; her tüketici kendine özgü değer ve inançlar, deneyim, sosyal çevre, duygusal durum ve bilişsel yapı içerisinde özgün bir kişilik özelliği (personal trait) sergilese de sağlığını ilgilendirecek bir ürünü satın alma sürecinde bilgi arayışı içerisine girer, mevcut durumu değerlendirir ve risk/getiri analizi neticesinde eyleme geçeceği söylenebilir.

Aertsens ve arkadaşları (2009b: 1150) de organik ürün tüketiminde temel sınırlamalarda organik sertifikasyon sürecine ilişkin duyulan güvensizliği temel faktörlerden biri olarak bulgulamışlardır. Sonuç olarak tüketiciler açısından bu ürünlerde finansal risk yüksektir ve bu sonuç tüketici nezdinde daha fazla güven ihtiyacı doğurmaktadır. Bu nokta da sertifikalı organik ürünler ile doğal/naturel kavramı kullanılarak satılan ürünler arasında fark olduğunun vurgulanması da önemlidir. Fotopoulos ve Krystallis (2002)'e göre ise organik gıda ürünü satın alma davranışı, çevreci/etik türde bir kalite/sağlık bilinci ile keşifsel gıda alışveriş davranışlarının yanı sıra besin değeri, tat ve fiyat gibi ürüne ilişkin özelliklere dayanmaktadır. Tüketicilerin ekoloji ve çevrecilik hakkındaki bilgileri arttıkça çevre dostu ürünleri satın alma istekleri de artmakta (Kacur, 2009: 253) ve organik ürünlere yönelik pozitif tutum sergilemelerinin, organik ürünler konusunda daha fazla bilgilendirilmeleriyle mümkün olacağı saptanmıştır (Ersun ve Arslan, 2010: 117). Özetle; davranışsal bölümleme kapsamında değerler (insan ve doğal çevre tarafından şekillendirilen), risk algılaması, bilgilendirme ve güven kavramları organik ürün satın alma davranışında önemli kavramlar olarak ele alınabilir. 


\section{Organik Tarım Ürünlerinde Pazarlama Karması}

Başarılı bir organik ürün pazarlaması diğer sektörlerde olduğu gibi; talep ölçmede iyi bir planlama, arzdaki boşlukları bulma ve tüketicilere ulaşmak için gerekli yolları ortaya çıkarmayı gerektirir. Bu sektörün içerisinde yer alan oyuncular, organik üretimin sağladığı sosyal, çevresel ve etik faydaları destekleyici eğitimsel pazarlama kampanyaları ile daha geniş müşteri bölümlerinin alg1 ve davranışlarını değiştirmeyi hedeflemelidir (McEachern ve McClean, 2002: 85). Özellikle gelişmiş ülkelerde tüketicinin tarımsal ürünlerde satın alma davranışı yönünü organik ürünlere çevirmiştir. Üretici ya da örgütler, hedef pazarlarını belirledikten sonra ürünlerine yönelik uygun pazarlama bileşenleri stratejisi geliştirmelidir. Organik gıdaların pazarlama sürecinde, trendlerin ne yönde ilerlediği, tüketicilerin üründen bekledikleri faydalar ile satın alma davranışları, organik ürünlerin tasarımı, standardı ve çeşitliliğini belirleyen faktörlerdir. Üreticiler, pazardaki tüketici eğilimlerinin ve davranışlarının sürekli olarak değişebileceğini dikkate alarak pazarda yer alan ürünler ile rakiplerin analizini gerçekleştirmeli ve çevre koşullarını değerlendirmek üzere SWOT analizleri yaparak kendilerinin güçlü ve zayıf yönlerini, pazardaki fırsat ve tehditleri ortaya koymalıdırlar (Akat, 2000: 120).

Anketler; sosyo-demografik özellikler, müşteri tipolojisi, satın almada erişebilirlik ve yer, algılamalar ve motivasyonlar, organik etiketler ile ilgili bilgiler ve engeller gibi tüketicinin organik ürünlere ilişkin fiili satın alma davranışını ele almış (TNS, 2004; akt. Padel ve Foster, 2005: 608) ve bu sonuçlar doğrultusunda izlenecek stratejiler literatürde ileri sürülmüştür. Bu bağlamda, Kılıç ve arkadaşlarının (2014) Türkiye'de 40 organik ürün üreticisinin pazarlama bölümü müdürleri ile gerçekleştirdikleri çalışmasında, organik ürünlerin pazarlama stratejilerine yönelik ulaştıkları bulgular Tablo 1'de görülmektedir.

Tablo 1: Organik Ürünlerin Pazarlama Stratejileri

\begin{tabular}{|l|}
\hline * Ürün Stratejileri \\
\hline $\begin{array}{l}\text { Hedef Pazar: } 20-40 \text { yaş aralığında olan kadınların ve çocuklu müşteriler ile gelir düzeyi } \\
\text { yüksek organik pazar müşterileri }\end{array}$ \\
\hline \begin{tabular}{l} 
Ürün Kategorileri: Yaş, kurutulmuş ve dondurulmuş sebze ve meyve ürünleri, Akdeniz \\
ürünleri, meyve suyu konsantreleri ve baklagiller ürün grubu \\
\hline Yeni Ürün Geliştirme Kararı: Tüketicilerin talebi doğrultusunda \\
\hline $\begin{array}{l}\text { Ambalajlama: Farklı renk ve boyutlarda, ürünü koruyacak özellikte, renk ve tasarım } \\
\text { açısından ise dikkat çekici }\end{array}$ \\
\hline * Fiyatlama Stratejileri: Pazarın kaymağını alma stratejisi \\
\hline *Dağıtım Stratejileri: Ekolojik veya organik pazarlar, az sayıda etkin aracı \\
\hline *Tutundurma Stratejileri: Mağaza içi reyon düzenlemeleri, mağaza içi tanıtımlar, reklâm \\
ve kişisel satış çabaları
\end{tabular} \\
\hline
\end{tabular}

Kaynak: Kılıç vd. (2014).

Türkiye'deki organik tarım pazarı, dünya organik pazarları kadar hızlı gelișememektedir. Bunun en önemli nedenleri pazarlama stratejilerinin eksikliği ve ihraç ürünlerinin yetersiz düzeyde gelişimi olarak görülmektedir (Ifoam, 2010; akt. Kılıç vd., 2014: 41). Diğer taraftan, organik ürünlere olan talep diğer ülkelere göre gelişmiş ülkelerde daha fazladır. Bu durumun nedenleri ise şöyledir (Yanmaz, 2011; akt. Eti, 2014: 18):

- Yaşam kalitesinin ve gelir düzeyinin yüksek olması.

- Yiyeceklerde tat unsurunun önem kazanması. 
- Çevreyi korumaya yönelik bilincin ve duyarlılığın artması.

- Gıda güvenliği konusunda insanların ve tüketicilerin daha bilinçli hale gelmeleridir.

Ürün çeşitliliğinin artması, firma bazında üretim maliyetlerini, genel pazarlama ve nakliye giderlerini düşürecektir. Ayrıca her yeni ürün, yeni tüketicilerin oluşmasını sağlayacak yani talep artışını beraberinde getirecektir. Az ürünle gerçekleştirilen organik tarım, arz-talep dengesinin oluşturulmaması nedeniyle üretim aşamasında çiftçilerin, pazarlama aşamasında firmaların zorluklarla karşılaşmasına neden olacaktır (Güzel, 2001; 72). Bu tespit doğru olmakla beraber, ürün çeşitliliğini maksimize etme noktasında firmaların birtakım stratejileri izlemesi de gereklidir. Örneğin, Aertsens ve arkadaşları (2009a: 144-145) organik ürünlerin pazarlanmasında Belçikalı üç ana perakendecinin pazarlama stratejilerini incelemiştir. Birinci strateji, yüksek kalite, bulunabilirlik ve sağlıklı ürün arayan hedef kitlesine, toplam ürün gamının \%4'ü ne tekabül eden 650 organik ürün çeşidi ile hizmet vermektir. İkinci strateji, pazarlama noktasında özel bir çaba içine girmeden, toplam ürün gamının \%2,6'sına tekabül eden 236 yüksek ve düşük fiyat kategorisiyle tüm pazara hitap etmeyi hedeflemektedir. Son perakendeci ise özellikle verimli bir "operasyonel karışım”" (operational mix) ya da düşük maliyetli bir lojistik üzerine odaklanmakta ve 190’1 özel markadan oluşan 312 çeşit organik ürün cirolarının \%2'sini oluşturmaktadır (Aertsens vd., 2009a: 144-145).

\section{1. Ürün}

Ürün kapsamında amaç, pazarlanabilir olan malı planlamak ve geliştirmektir (Sümer ve Eser, 2006: 167). Özellikle g1da perakendeciliğinde, müşteriler hangi ürün kararını vereceklerini bilmeden mağazalara girerler, ancak yeni ürünleri keşfetmek ve değerlendirmek için mağazaya göz atmaya istekli olurlar (Blut vd., 2018: 116). Bu süreçte müşteriler satın alma kararlarını verirken kendileri için en uygun ve yararlı olan ürünleri tercih etmektedirler (Babacan, 1998: 6). Yapılan araştırmalar organik ürün satın almada en güçlü açıklama olan sağlığın "değer güvenliği” ile ilgili olduğunu gösterir (Aertens vd., 2009b: 1156). Bu bağlamda tüketici değerini maksimize edecek önemli bir faktör olan "sağlık", organik ürünlere ilişkin iletişim stratejisini tasarlamada merkeze alınacak bir faktör olarak düşünülmelidir. Bu temel faktör hedonizm, zevk ve başarı gibi değer unsurlarıyla (Zanoli ve Naspetti, 2002:652) da birleştirilebilir.

Organik pazar sektöründe iş yapabilmenin en önemli aşaması, tüketicinin ürünün organik olduğuna inanması ve ikna olmasıdır. Günümüzde tüketiciler, sürdürülebilir olan ve olmayan ürünleri seçmek yerine sürdürülebilir ürünler arasında bir tercih yapmak istemekte (Shafie ve Rennie, 2012: 361) ve ürünlerin gerçek organik kalitesi hakkında daha fazla güvence talep etmektedir (Padel ve Foster, 2005: 621). Organik ürünlerin satışında ürünün sertifikasyonu gerekliliklerden biridir ve ürünün bir sertifikasyona sahip olması tüketicinin güvenini destekleyecektir (Eti, 2014: 33). Organik ürün üreticileri, pazarın yeni ürünlere olan tepkilerini yakından izlemeli ve bu bilgilere dayanarak organik ürünlerini geliştirmelidirler (Orgüder, 2011; akt. Kılıç vd., 2014: 43). Üreticiler ve bu ürünleri işleyen örgütler, çabuk bozulmayan, lezzetli, kullanımı kolay ve duyusal kalite standartlarına uygun (tüketicilerin duyularına hitap eden) organik ürünleri geliştirmeyi hedeflemelidirler (Zanoli ve Naspetti, 2002: 652).

Organik ürünler içeriklerine göre üçe ayrılmaktadır:

- %100 Organik Ürün: Nihai ürünün içeriğindeki maddeler tamamen organik,

- Organik Ürün: Nihai ürünün içeriğindeki maddeler en az \%95 oranında organik, 
- Organik Maddelerle Yapılmış Ürün: Nihai ürünün içeriğindeki maddeler en az \%70 oranında organik.

Organik üretim sürecinde genetik değişime uğramamış veya kirli su atıklarında üretilmemiş konvansiyonel tarım ürünleri kullanılmalıdır (Ersun ve Arslan, 2010: 26). Organik ürünlerin ambalajlama, paketleme ve etiketleme gibi pazarlama unsurları açısından yetersiz olması (Nasır ve Kımıloğlu, 2006: 409) organik ürünlere ilişkin talebin yeterince gelişmemesinin nedenleri arasındadır. Aşağıda bu faktörlere organik ürünler perspektifinden değinilmiştir.

\subsubsection{Ambalajlama}

Organik ürünlerin ambalajlanması; organik ürünlerin pazara sunulmadan önce organik niteliğini bozmadan paketlenmesi, ambalajlanması ve markalanması esnasındaki tüm işlemlerdir (Kurt, 2006: 21). Ürünlerin ambalajlanması ve pazara ambalajlanmış olarak sürülmesi pazarlamanın etkili bir şekilde çalışmasını arttırmaktadır (Yurdakul, 2004). Bir iletişim aracı olarak da düşünülebilen ambalajlama ürünleri koruma, fiyatlandırma, rakiplerden farklılaştırma, tüketicide yarattığı imaj ve satın alma isteği uyandırma, depolama, taşıma ve tutundurma gibi konularda etkisi ve katkısı olan bir unsur olup önemi modern pazarlama anlayışında giderek artmaktadır.

Tüketici ile iletişim kurması, tüketicinin dikkatini çekmesi, benzer ürünlerden farklılık yaratması, ürünün raftaki görünürlügünü artırması, satın alma sonrasında kullanım yararı sağlaması ve yaratıcılığı yansıtarak imaj geliştirmeye yardımcı olan ambalajlama doğada çözülebilir geri dönüşümlü malzemelerden seçilmelidir (Subaşı, 2005; 37). Ambalajlar üzerinde kendilerine ait özel marka ile organik ürünlerini sunan büyük perakendeciler de bulunmaktadır. $\mathrm{Bu}$ perakendeciler, markalı organik ürünlere göre özel markalı organik ürünlerini daha düşük fiyattan tüketicilere sunmaktadırlar. Örneğin, Wal-Mart bu alanda lider olmayı amaçlamakta ve özel markalı organik ürünlerini geleneksel ürünlerden \%10 daha pahalı fakat markalı organik ürünlere göre daha düşük fiyata satmaktadır (Park, 2009:483). Neticede fiyatları görece pahalı olan organik ürünlerin satışı noktasında ambalajlamanın bu ürünler için önemli olduğu söylenebilir.

\subsubsection{Etiketleme}

Organik etiketleme; ürünün organik olduğunun yazı, resim veya sembol şeklinde belirtilmesi, ticari marka, lisans ve patent alınması ile ilgili işlemleri içerir (Kurt, 2006: 22). Tüketicilerin, sertifikasyon ve etiketlemeyi gıda güvenliğini sağlayan bir referans olarak algılamaları sağlanmalıdır (Zanoli ve Naspetti, 2002: 652). Etiketleme kararları sadece tüketicilerin doğru bilgilendirilmesi değil, ekonomik etkinliğin artırılmasının da önemli bir aracıdır. Tüketiciler organik ürünleri satın alarak ilave ne değer elde edeceklerini bilmek istemektedirler (Kılıç, 2014: 46). Bu boyutuyla etiketlemenin değeri, tüketicilerin ürün üzerindeki etiket bilgileri ile ilgilenmelerine ve bu bilgileri değerlendirmelerine bağlıdır. Dolayısıyla tüketicilere etiketleri aktif şekilde kullanım alışkanlığının kazandırılması özellikle yasa koyucu ve modern pazarlama sistem ve süreçlerini benimsemiş işletmeler için öncelikli bir konu olmaktadır (Greene ve Jessup, 2001: 118).

Bir araştırmada organik ürün satın alan ve almayan tüketiciler bu ürünleri satın alırken daha iyi bilgilendirilmek ve organik sertifikasyon süreci hakkında daha fazla ek bilgi almaktan memnun olacaklarını belirtmişlerdir (Makatouni, 2002: 346). Mintel’e (2000) göre “organik” 
ve organik etiket isimleri, kişisel iyi olma hali ve sağlık bağlamında tüketicilerde güçlü duygusal yankılaşım (emotional resonance)'a sahiptir.

Etiketleme hem talep elde etme hem de fiziksel dağıtım fonksiyonlarına hizmet eder (Tek ve Özgül, 2007). İhraç edilen organik ürünlerin etiketlerinde; ihracatçı firma ismi, organik tarım işletmecilik sistemine göre üretilmiş ürün ibaresi, gerekirse üretici ismi, onaylayan kontrol organizasyonunun ismi, numarası, logosu veya amblemi kullanılmalıdır (Ayan ve Bayturan, 2002: 54). Sonuçta organik ürünler için etiket, tüketicinin korunması ve onların yararlanacağı önemli bir bilgi kaynağı olmasının yanında, organik ürünün güvenirliliğini de belirleyen bir belge niteliğindedir.

\subsubsection{Markalaşma ve Avantajlart}

Marka kavramı hem üretici hem tedarikçi hem de tüketici üçgeninde önemli bir faktör olup, günümüz yoğun rekabet ortamında örgütlerin sürdürülebilir rekabetçiliğine fayda sağlayan bir pazarlama uygulamasıdır. Kalite ve bulunabilirlikteki istikrar perakendeci için önemli prestij kaynağı olup perakendecilerin bu avantajları korumaları müşteri sadakatini artıracaktır (Albayrak ve Dölekoğlu, 2006: 215). Markalaşma tüketiciye yönelik kalite algısı yaratmada son derece önemli bir süreç olduğundan, fiyatları görece pahalı organik ürünler için bu algı önemli bir kavram durumundadır. Gıda güvenliği gibi konularda güvenilirlik elde etmenin en basit yolu, markalaşma şeklinde bir kimlik sağlamaktır (Lamb, 1994).

Marka, tüketicilerin bilişsel yapılarına tesir ederek, onların zihinlerinde ürünlere ilişskin bir kimlik algısı oluşturma ve bu algının olumlu olması ile de örgütlere Dünya’ya açılabilme, yüksek fiyatlandırma ve rekabetçi kalabilme gücü sağlar. Ülkemizin organik tarım ürünleri ihracatı, üretilen ürünlerin kalitesi ve ürün çeşitliliği gibi konularda önemli üstünlüğü bulunmaktadır (Kılıç vd., 2014: 40). Fakat organik tarım sektöründe markalaşamamak önemli bir sorundur. Markasız ürünlerimiz ihraç edildiği ülkelerdeki firmalarca etiketlenerek pazarlanmaktadır. Ufak üretici ve örgütlenmelerin bir araya gelmesi ve kooperatifleşmesi, özellikle yurt dışı pazarlara açılma noktasında üzerinde hassasiyetle durulması gereken bir konudur. Ayrıca gıda endüstrisindeki marka yöneticileri, güçlü markalar oluşturma çabalarında kaliteli bir görüntüye öncelik veriyor gibi görünmektedir (Anselmsson ve Bondesson, 2013; Davcik ve Rundquist, 2012. Akt. Anselmsson vd., 2014: 90). Sonuçta pazarlama karması içinde yer alan "ürün" kapsamında kalite, güvenilirlik ve ambalajlama unsurları markalaşma noktasında önemli faktörler olarak öne çıkmakta ve özellikle örgütlerin ihracat sürecinde ayrı bir önem arz etmektedirler.

\subsection{Fiyat}

Her şeyin gerçek fiyatı, onu elde etmek isteyen kişiye olan maliyeti ile onu elde etmek için katlandığı eziyet ve zahmettir (Smith, 2017: 29). Pazarlama karmasının diğer bileşenleri bir maliyet unsuru iken fiyat gelir yaratan bir bileşendir. Fiyatın sembolik olarak taşıdığı anlam, hedef pazarın yaşam biçimi, beklentileri veya toplumun yüksek fiyata yaklaşımı gibi ekonomik olmayan faktörler fiyat kararlarını etkileyebilmektedir (Subaş̧, 2005: 43).

Organik ürünlerin fiyat oluşumu, tüketicilerin ödemeye razı oldukları fiyat, gelir ve eğitim seviyesi, tüketim alışkanlıkları, tüketici bilinci ve pazarlama alt yapısı gibi faktörlerin etkisiyle oluşmaktadır (Eti, 2014: 54). Fiyat tüketicinin karmaşık satın alma karar sürecinde önemli olsa da sadece bu süreci etkileyebilen faktörlerden biridir. Organik ürünlere ilişkin temel sorunlar farklı tüketicilerin farklı algılamaları nedeniyle çeşitlilik göstermektedir. Tüketicilerin 
çoğu fiyatı temel sorun olarak gösterirken, diğer tüketiciler bu ürünlerin "yeterince yaygın olmaması"nı ve “organik ürünlere ilişkin bilgi eksikliği”ni temel sorun olarak görmektedirler (Ersun ve Arslan, 2010: 129). Organik gida kavramının zihinlerinde pahalı olarak konumlanması bu sektör için bir dezavantaj olarak görülse de organik ürün satın alanlar algılanan gıda güvenliği riskini azaltmak için ürünlere daha fazla para ödemeye razı olan kişilerden oluşmaktadır (Williams vd., 2000). Ayrıca düzenli tüketiciler ve erkeklerin, daha yüksek fiyat ödeyebilecekleri dile getirilmiştir (Biemans, 2011: 125).

Batte ve arkadaşları (2007: 145) geleneksel ürünlerle karşılaştırıldığında tüketicilerin organik ürünlere daha yüksek fiyat ödemeye razı olduklarını ortaya koymuşlardır. Bu noktada organik ürün fiyatlarının neden yüksek olduğunu tüketiciye kitle iletişim araçları, ambalajlar ya da bireysel satış aracılığıyla aktarılabilmesi gereklidir. Ayrıca ürün kalitesi sağlıkla eşdeğer kabul edilirse, organik ürünlerin fiyatının düşürülmesi, bu ürünlerin farklı olma özelliğini azaltabilir ya da diğer bir ifadeyle ürünün sağlıklı olma algısını azaltabilir. Bu nedenle, kalite ve fiyat arasındaki dengeyi sağlayacak şekilde bir fiyatlandırma yapılmalıdır (Hughner vd., 2007: 10-13).

Tüketiciler, yüksek fiyatları yüksek kalite ile ilişkilendirirler (Kılıç, 2014: 48). Organik ürünler "değer stratejisi” kapsamında ele alınmalı ve üreticiler ürün farklılaştırmaya önem vermelidirler. Ürün farklılaştırma ile tüketicilerin ürünü daha değerli olarak algılamaları ve dolayısıyla ürünün daha yüksek fiyatla satılabilmesi mümkün olabilmektedir (Baltacıoğlu ve Kaplan, 2007: 51). Ayrıca yüksek fiyatlı organik ürünlerin pazarlanması noktasında örgütler "hedonizm" kavramını besleyicilik ve güç temaları ile destekleyerek kullanabilirler. Tüm fiyat nihayetinde aynı üç parçadan oluşur: rant, emek ve kâr (Smith, 2017: 48). Sonuçta örgütler en çok fayda sağlayan ve en düşük fiyatla (uygun fiyat) rakiplerinden farklı olan ürünlerin sunulması olarak tanımlanan müşteriye değer sağlamayı gerçekleştirmek durumundadırlar (Altıntaş, 2000: 5).

\subsection{Tutundurma}

Tutundurma ürüne, markaya ve kuruluşa karşı olumlu bir görüş benimsemeye özendirmek amacıyla yapılan bilinçli, programlanmış ve düzenli faaliyetlerden oluşan bir iletişim sürecidir (Subaş1, 2005: 43). Emtiaların ya da ticarete konu olan ürünlerin tüketici talebinin arttırılması için reklam ve tanıtıma ihtiyacı vardır. Tüketicilerin gıda tüketimindeki bilinç düzeylerini belirleyen en önemli unsur televizyon, gazete, radyo ve sosyal medya gibi kitle iletişim araçlarının konu ile ilgili yayınlarıdır (Dalkıran, 2009: 156). Bu doğrultuda tutundurma organik ürünlere yönelik talep sürekliliğini sağlamada etkin ve verimli kullanılmalıdır.

Organik ürünlerin pazarlanmasında en önemli sorunun organik ürünlere ilişkin gerekli güvenin sağlanamaması olduğunu söylemek mümkündür (Ersun ve Arslan, 2010: 129). Ayrıca tüketicilerin organik ürünlerin yararlarını veya değerini algılayamamaları, bu ürünlerin her yerde bulunmamaları ve/veya organik ürünlerin tutundurmasının etkin bir şekilde yapılmamasından kaynaklanmaktadır (Hughner vd., 2007:11). Organik ürünün tüketicinin zihninde konumlandırmasında bilgi düzeyi önemlidir. Çünkü tüketiciler daha fazla bilgiye ihtiyaç duymaktadırlar (Kılıç vd., 2014: 44). Soler vd., (2002)'e göre, bilginin değil, bilginin veriliş şekli tüketicilerin satın alma gönüllülüklerini etkiler. Bu da tutundurma kampanyasının nasıl yapılması gerektiği hakkında önemli ipuçları ortaya koymaktadır. Aşağıda Tablo 2'de örgütlerin tutundurma faaliyetlerinde vurgulayabilecekleri organik ürünlerin tercih edilme nedenleri, uluslararası düzeyde yapılan araştırmalar perspektifinden yer almaktadır. 
Tablo 2: Tüketici Tutumunu ve Organik Gıda Talebini Etkileyen Faktörler

\begin{tabular}{|c|c|c|c|}
\hline Araştırma Konusu & Yazar & $\begin{array}{l}\text { Ülke Kaynağı } \\
\text { / Metodoloji }\end{array}$ & Faktörler \\
\hline $\begin{array}{l}\text { Durumların satın } \\
\text { alma niyeti ve } \\
\text { davranışı üzerindeki } \\
\text { etkisi }\end{array}$ & Grimmer vd., (2015) & $\begin{array}{l}\text { Avustralya / Görgül } \\
\text { test (Empirical test) } \\
(\mathrm{n}=772)\end{array}$ & \multirow{2}{*}{$\begin{array}{l}\text {-Fiyat } \\
\text {-Ulaşılabilirlik } \\
\text {-Satın alma kolaylığı } \\
\text {-Ön bilgi } \\
\text {-Yüksek gelecek } \\
\text { yönelimi (High levels } \\
\text { of future orientation) }\end{array}$} \\
\hline $\begin{array}{l}\text { Organik gidaların } \\
\text { tüketimi için fayda } \\
\text { segmentasyon } \\
\text { tabanının bir uzantısı. }\end{array}$ & $\begin{array}{l}\text { Gad Mohsen ve Dacko } \\
\text { (2013) }\end{array}$ & $\begin{array}{l}\text { İngiltere /Anket } \\
\text { (Korelasyon ve } \\
\text { Regresyon) }\end{array}$ & \\
\hline $\begin{array}{l}\text { Organik gıdaların } \\
\text { satın alma davranışını } \\
\text { etkileyen faktörler. }\end{array}$ & $\begin{array}{l}\text { Shamsollahi vd., } \\
\text { (2013) }\end{array}$ & $\begin{array}{l}\text { Malezya / Anket } \\
\text { (Tanımlayıcı analizler, } \\
\text { korelasyon ve katsayı } \\
\text { analizleri) }\end{array}$ & \multirow{2}{*}{$\begin{array}{l}\text {-Bilgi ve Eğitim } \\
\text {-Çevresel kaygılar } \\
\text {-Sağlık bilinci } \\
\text {-Talep fiyata esnek } \\
\text { değil (Demand is price } \\
\text { inelastic.) }\end{array}$} \\
\hline $\begin{array}{l}\text { Organik sütün talep } \\
\text { analizi. }\end{array}$ & & $\begin{array}{l}\text { Almanya / } 20000 \\
\text { Hanenin fiyata } \\
\text { esnekliği (Price- } \\
\text { elasticity of } 20000 \\
\text { households.) }\end{array}$ & \\
\hline $\begin{array}{l}\text { Satınalma davranışı } \\
\text { ve sosyo ekonomik } \\
\text { faktörlerin organik } \\
\text { gıda ürünlerine ilişkin } \\
\text { etkisi. }\end{array}$ & Santhi vd., (2007) & $\begin{array}{l}\text { Hindistan / Anket } \\
\text { (Tanımlayıcı } \\
\text { istatistikler, ANOVA } \\
\text { ve Faktör analizi) }\end{array}$ & \multirow{3}{*}{$\begin{array}{l}\text {-Medeni durum } \\
\text {-Gıda alışkanlıkları } \\
\text { (vejeteryan) } \\
\text {-Etik bağlılık } \\
\text {-Gıda güvenliği } \\
\text {-Ulaşılabilirlik } \\
\text {-Gelir } \\
\text {-Sağlık ve çevresel } \\
\text { kaygılar } \\
\text {-Ürünlerin görsel } \\
\text { çekiciliği } \\
\text {-Kalite ve Güvenlik }\end{array}$} \\
\hline $\begin{array}{l}\text { Organik gıda satın } \\
\text { almak için düzenli ve } \\
\text { seyrek gelen } \\
\text { tüketicilerin } \\
\text { niyetlerini belirleyen } \\
\text { faktörler. }\end{array}$ & Pino vd., (2012) & $\begin{array}{l}\text { İtalya / Anket ve } \\
\text { Yapısal Eşitlik } \\
\text { Modellemesi }\end{array}$ & \\
\hline $\begin{array}{l}\text { Slovenya'daki organik } \\
\text { ve entegre meyve ve } \\
\text { sebzeler için satın } \\
\text { alma davranışının } \\
\text { belirleyicileri. }\end{array}$ & $\begin{array}{l}\text { Shamsolla ve Juvancic } \\
\text { (2010) }\end{array}$ & $\begin{array}{l}\text { Slovenya / Anket } \\
\text { (Siralı Probit Modeli / } \\
\text { Ordered Probit Model) }\end{array}$ & \\
\hline
\end{tabular}

Kaynak: Rana, J ve Paul, J. (2017).

Daha önceki yıllarda yapılan araştırmalarda, sağlık, çevre ve lezzet kavramları sıralaması tüketicilerin organik ürünleri tercih etmelerinin önemli faktörleri (Aksoy, 2003) olarak karşımıza çıkmıştır. Fakat organik gıda talebi, ürün seçiminden araştırma yapılan tüketici kitlesine, odaklanılan coğrafi bölgeye, konuya ilişkin araştırmalara (yöntem ve teknikler) ve bölümlendirme kriterlerine kadar çeşitlilik veya farklılık arz edebilir. Tablo 2'ye bakarak 
günümüzde bu kavramlara ek olarak, ulaşılabilirlik, gelecek yönelimi, bilgi, etik bağlılık ve eğitim gibi kavramların öne çıktığı görülmektedir.

McEachern ve McClean (2002: 89) İngiltere de organik mandıra ürünlerine yönelik tüketicilerin satın alma motivasyonu ve demografik verileri arasında çapraz değerlendirme yaptıkları çalışmalarında, 41 ile 50 yaş aralığının ana motivasyon kaynağının gıda güvenliği, 18-25 ve 31-40 yaş aralıklarının ana motivasyonlarının ise tat (taste) olduğu belirlemiştir. Stobbelaar vd., (2007) de Hollandalı yetişkinler üzerinde gerçekleştirdikleri çalışmalarında "lezzet" i organik ürün satın almada en önemli sebep olarak bulmuşlardır. Sondhi ve Vani, (2007) ise tüketicinin ürünün yararlarını anlayabilmeleri için, ürünün nasıl yararlı olduğunun gösterilmesine ihtiyaç duyduklarını bulgulamıştır. Neticede ürün özellikleri tüketiciye iyi anlatılabilirse, organik ürünlerin geleneksel ürünlere oranla daha fazla tercih edilmesi mümkün olabilecektir (Hill ve Lynchehaun, 2002).

Tüketicilerin organik ürünleri satın almama nedenleri değerlendirildiğinde, organik ürünlerin pahalı olması, sınırlı bulunabilirlik, organik ürünlerde tatmin edici olmayan kalite, mevcut satın alımlardan duyulan tatmin düzeyi, güven eksikliği, algılanan değerde eksiklik ve organik yollardan üretimi anlama eksikliği en önemli konuları oluşturmaktadır (Essoussi ve Zahaf, 2008: 96).

\subsection{Dağıtım}

Organik olarak üretilmiş olan ürünler, son tüketicisine ulaşana kadar çeşitli işlemlere ve yollara maruz kalırlar. Bu çeşitli yolların ve işlemlerin bütününe "dağıtım kanalları” denilmektedir (Yurdakul, 2004). Dağıtım kanalları, organik ürün için hayli önem kazanan bir pazarlama karmas1 aracıdır (Eti, 2014: 62). Süper/hipermarketler gibi perakende zincirleri, özellikli mağazalar, doğal ürün satan mağazalar (uzmanlaşmış mağazalar), semt pazarları, toptancılar, üretici tarafindan doğrudan satış ve internet kanalıyla satış organik ürünler için başlıca dağıtım kanallarını ifade etmektedir (Kurt, 2006: 27). İyi işleyen bir dağıtım lojistiği sistemi, tüketicin ürünü talep ettiği zaman optimum koşullarda (fazla stok yapmadan, fazladan taşıma maliyetlerine katlanmadan) onun ürüne erişimine olanak vererek yer, zaman ve mülkiyet faydası sağlar.

Organik ürün satın almanın önündeki engellere yönelik tartışmalar, fiyat noktasında yoğunlaşsa da erişim ve bulunabilirlik konuları da gün yüzüne çıkmıştır (Padel ve Foster, 2005: 619). Tüketiciler daha çeşitli, daha kaliteli ve daha sağlıklı gıda ürünleri aramasına rağmen, organik ürünler dağıtım kanallarındaki eksikliklerle ilgili sorunlarla karşı karşıyadır (Roddy vd., 1994). Taze sebze ve meyvenin organik gıda mağazalarına, doğal gıda mağazaları veya diğer perakende satış kanallarına düzenli olarak tedarikinin yüksek lojistik maliyetler nedeniyle mümkün olmaması, satış artışını engellemektedir (Ersun ve Arslan, 2010: 129). Üreticiler ile tüketiciler arasındaki etkin olmayan aracıların ortadan kaldırılması ya da ürünlerin direkt olarak tüketicilere ulaştırılması ile organik ürünlerin yüksek fiyatları daha düşük düzeylere çekilebilir (Kenanoğlu ve Karahan, 2002:315). Bu noktada üretici veya çiftçilerin, tüketiciye direkt satış (internet, halk pazarları) alternatiflerini değerlendirmeleri ürünlerine ayrıca katma değer katacaktır. Bu vasıta ile bir başka dağıtım kanalını daha tanımlama imkânı oluşabilir.

Via ve Nucifora (2002:319) tarafindan dört Avrupa ülkesinde (Fransa, Almanya, İspanya ve İngiltere), 47 mağazada yapılan çalışmada, perakendecinin büyüklüğünün, konumunun, imaj1 ve kalitesinin, ürün bilgisi düzeyinin ve müşteri hizmetlerinin organik ürünlerin satın alınmasında etkili olduğu bulunmuştur. Örneğin, A.B.D.'de süper marketlerdeki genel eğilim, müşteri kartları sayesinde toplanmış olan elektronik veri tabanlarının kolaylaştırdığı mikro 
pazarlamaya yönelmiştir. Bu uygulama, perakendecilere organik ürünler gibi özel ürünlerde daha iyi bir hedef kitleye ulaşmada yardımcı olmuştur (Klonsky, 2000: 233).

Doğal ürün satan mağazalar da organik ürün pazarlanmasında en az süpermarketler ve hipermarketler kadar ön plandadır. Bu mağazalar, farklı çeşitte organik tarım ürünlerine uzmanlaşmış olduklarından satışları oldukça yüksektir (Kurt, 2006: 27). Ayrıca tüketiciler süpermarketlerin organik ürünleri daha da pahalı yaptığı ve bunun karşılığında üreticiye yeterli ödeme yapmadığını düşünmektedir (Padel ve Foster, 2005: 620). Dolayısıyla bu özellikli mağazalara yönelik etkin bir dağıtım planlaması yapmak hem satışları hem de bu ürünlerin erişimi ve bulunabilirliği açısından örgütlere katk1 sağlayacağı düşünülebilir. Zira perakendeciler için müşteri sadakatinin sürdürülmesi son derece önemlidir (McEachern ve McClean, 2002: 87).

\subsubsection{Dağıtımın Kanalları ve Planlanması}

Dağıtım kanallarının yönetimi şeklinde de ifade edebileceğimiz lojistik yönetimi bir anlamda siparişin üretilmesi, siparişin alınması, siparişin yerine getirilmesi ile ürünün, hizmetin veya bilginin dağıtımının koordinasyonunun sağlanmasıdır (Eker, 2006: 4). Dağıtım kanalları, üretici/satıcı ile tüketiciyi dolaylı olarak bir araya getirmek (eşleştirme) gibi önemli bir hizmeti sağlarlar. İyi bir planlama yapılmadan gerçekleştirilen dağıtım faaliyetleri yer ve zaman faydası sağlamamasının ötesinde, dağıtım zincirlerine yeni halkalar/maliyetler de ekleyerek örgütlere iktisadi sorunlar yaratacağı ortadadır.

Dağıtım planlamasına hedef kitlenin nerde ve ne zaman var olacağına yönelik araştırmalar ile başlanmalıdır. Organik tarım ürünlerinin önemli pazarlama kanallarında[n] birisi de turizm işletmeleridir (Dalkıran, 2009: 157). Bölgelerin sezon ve tüketici kesimi dikkate alınarak, pazar koşulları ve yapılacak pazarlama eylemlerine ilişkin bilgilerin toplanması, satış noktalarının belirlenmesi gerekir. Örneğin şehirde ikamet eden orta-üst gelir grupları yaz aylarını belli bazı turistik bölgelerde geçirmekte ve organik ürünlere olan talebi bu bölgelerde yaratmaktadırlar. Bu bölgelerde yoğun sezon boyunca menülerinde organik gida kullanan restoran ve otellerin yanı sıra perakendecilere de ulaşmak, üretici ve örgütler için gereklidir.

Tercih edilen ve satın alınan organik ürünler arasında en büyük payı (\%83), organik meyve ve sebzeler almaktadır. Organik ürün pazarlarında ve dağıtım kanallarında organik meyve ve sebzelerin ağırlıklı olarak yer tutması da bunun bir sonucudur (Ersun ve Arslan, 2010: 114). Raf ömürleri kısa ve herhangi bir koruyucu madde içermeyen organik ürünlerin ihtiyaç duyacağı muhafaza ve taşıma işlemlerinin alanında uzmanlaşmış işletmelerce yapılması, müşteri güveni ve bağlılığı sağlamanın yanında maliyet artışı bağlamında oluşabilecek sorunların da hafifletilmesine yardımcı olabilir.

“Evren ile uyum içinde olma” motivasyonu ile düzenli organik ürün satın alan tüketicilerin yanında, nadiren organik ürün satın alan tüketicileri güdüleyen önemli faktörler, bu ürünlere kolay ulaşılamaması ve uygun olmayan satış noktaları olmuştur (Zanoli ve Naspetti, 2002: 650). Tüketiciler organik gıdalara yönelik tüketici davranışlarında daha sofistike hale geldikçe, örgütler izlenebilirlik, yüksek kalite, yeterli tedarik hacmi ve tedarik sürekliliği sağlamak için tedarik zinciri yönetimine odaklanmaktadır (Aertsens vd., 2009a: 139). Ayrıca taşıma yönteminin belirlenmesi esnasında maliyet, devamlılık ve taşımanın ne süratle gerçekleşeceği üzerinde de durulmalıdır (Göksel ve Baytekin, 2005: 141).

Araya büyük mesafelerin girebildiği ithalat/ihracat süreçlerinde güven kavramının daha da önem kazandığg ifade edilebilir. Sonuçta, üreticilerin/örgütlerin tarımsal ürünlerde tüketici sayısının fazla ve coğrafi açıdan dağınık olması nedeniyle, alternatif dağıtım kanallarını ve 
organik ürünlerin özelliklerini tüm pazarlama işlemlerinde dikkate almak zorunda olması büyük önem taşımaktadır (Mutlu, 2008) ve bu işlemler hatasız yapıldıkça, taraflar arasında güven zamanla tesis edilecektir.

Organik tarım iç pazarın talebini karşılamak amacıyla değil, ihracat amacıyla ortaya çıkmıştır (Aytoğu, 2006). Organik tarımın sağladığı iki önemli avantaj mevcuttur. Bunlardan birincisi, uluslararası piyasalarda güvenilir bir yer edinilmesi ve ihracatın teşvikidir (Güzel, 2001: 24). İhracatı gerçekleştiren kuruluşun ekonomik hedeflerinin olması doğaldır. Fakat bu ekonomik hedeflerin yanı sira dikkate alınması gereken bazı önceliklerde mevcuttur. Bu önceliklerden bazıları sırasıyla:

- Standartların yerine getirilmesi sırasında firmanın ekolojik ve sosyal amaçlarının ortaya konulmasi,

- Niş marketlerin ortaya çıkarılıp, firma için potansiyelin belirlenmesi,

- Uzun vadeli müşteri kazanmak ve bu müşterilerin korunmasıdır (Koç, 2009).

Her zaman ve her yerde, değerli olan az bulunandır ya da edinmek için fazla emek gerektirendir (Smith, 2017: 31). Doğal olarak organik ürünlerin üretilmesinde gereken emek ve hassasiyet, bu ürünlerin geleneksel tarzda yetiştirilen ürünlere nazaran daha nadide bir özellik göstermesine yol açar. Dolayısıyla, yüksek katma değer üretecekleri ihraç pazarlarında değerlendirilen organik ürünlerin standardı bozulmamalıdır. Özellikle organik standartların eşdeğerliliği konusunda bir güvensizlik hali ile kombine edildiğinde, organik ürünlerin ithalatı ve güvensizlik arasındaki ilişki kuvvetlidir (Padel ve Foster, 2005: 621). Sonuçta ihraç pazarlarında etkin olunması, pazarlama aşamasında birçok maliyet unsurunda tasarruf edilmesini sağlayacaktır. Ayrıca, ürün kalitesini sürekli olarak aynı seviyede tutmak önemli bir detaydır (Anonim, 2012; Akt. Eti, 2014: 36).

Organik ürünlerin depolanması; organik ürünlerin herhangi bir aşamada bekletilme/saklanma koşullarını tanımlamaktadır. Organik tarım ürünlerinin depolandığı alanlarda kullanılan yalıtım malzemeleri ve soğutma ile ilgili ekipmanlar da kimyasalların bulaşma riski göz önünde bulundurularak dikkatli bir şekilde seçilmelidir (Marangoz, 2008:110). Hasat döneminde çeşitli kalitede ve farklı fiyatlarda ürünler pazara çıkar ve genellikle bu dönemlerde üretimde dalgalanmalar, spekülatif fiyat artışları ya da arz fazlalığı ile karşılaşılır. Depolama bu yönüyle fiyatları dengede tutar hem üreticiyi hem de tüketiciyi fiyat açısından korur ve piyasada istikrarı sağlar. Ayrıca organik tarım ürünleri için zaman faydası sağlayarak, ürünlerin hasat döneminden daha sonraki bir dönemde pazara sunularak yüksek fiyattan satılmasını sağlar (Kurt, 2006: 29). Neticede üretici-toptanc1-perakendeci arasında iyi bir pazarlama ağının kurulması ve organik ürünlerin uygun koşullarda depolanması gerekir (Yanmaz, 2011: 11).

\section{Sonuç ve Öneriler}

$\mathrm{Bu}$ çalışma kapsamında sadece organik tarım ürünleri ve işlenmiş organik gıda ürünleri sektörü/pazarı ele alınmıştır. Bu çalışmada literatür bulguları ışı̆̆ında organik gıda tüketimini etkileyebilecek kavramların, 4P'de bir karma elemanı içerisindeki görünümünü ve önemini ortaya koyma amacı güdülmüştür. Üretimde kimyasal girdi kullanılmadan, her aşaması kontrollü ve sertifikalı olarak geliştirilen tüm ürünler "organik" olarak tanımlanmaktadır. Organik tarım ürünlerine olan talep azlığı iç piyasa ağırlıklı olarak pazarlama sıkıntısı doğurmaktadır. Örgütlerin 4P yoluyla nihai tüketiciye ulaşma, satın almaya ikna etme ve sadakatini sağlama sürecinde, müşteri yararını ön plana çıkaran kavramları bilmesi ve etkili kullanmasının yanında çekme stratejilerine imkanları ölçüsünde ağırlık vermeleri 
gerekmektedir. Bu amaca yönelik olarak, pazarlama karması elemanlarına, geleneksel yaklaşım ile organik tarım ürünleri açısından yaklaşım arasındaki farkların veya odak noktaları (ana temaları)'nın neler olabileceğine yönelik karşılaştırmalar Tablo 3’te yer almaktadır.

Tablo 3: Satın Alma Eğilimi ve Pazarlama Karması Elemanları Odakları

\begin{tabular}{|c|c|c|}
\hline $\begin{array}{c}\text { Pazarlama Karması } \\
\text { Boyutları }\end{array}$ & Geleneksel Odak & $\begin{array}{l}\text { Organik Tarım Ürünleri } \\
\text { Pazarlamasında Odak }\end{array}$ \\
\hline $\begin{array}{c}\text { Ürün } \\
\text { (Product) }\end{array}$ & $\begin{array}{l}\text {-Etkin üretim programı, satış } \\
\text { sonrası destekler, kaliteli hizmet ve } \\
\text { bilgi transferi (Bennett, 1997: } \\
\text { 155). } \\
\text {-Yüksek satın alma sıklığına sahip } \\
\text { olan (Süt, Ekmek vb. gibi) ürünler, } \\
\text { yüksek olasılıkla dürtüsel yolla } \\
\text { (impulsive manner) satın alınırlar } \\
\text { (Lee, 2008; akt. Hadjali vd., 2008: } \\
\text { 248). }\end{array}$ & $\begin{array}{l}\text {-Doğayı koruyan üretim teknolojileri } \\
\text {-Organik etiketleme (Mintel, 2000). } \\
\text {-Sağlık (Zanoli ve Naspetti, 2002: } \\
\text { 652). } \\
\text { - Yüksek gelecek yönelimi (Gad } \\
\text { Mohsen ve Dacko, 2013) }\end{array}$ \\
\hline $\begin{array}{c}\text { Fiyat } \\
\text { (Price) }\end{array}$ & $\begin{array}{l}\text {-Ölçek ekonomisi } \\
\text {-Rekabetçi fiyat/en düşük işletim } \\
\text { maliyeti (Bennett, 1997: 155). }\end{array}$ & $\begin{array}{l}\text {-Fiyat ve elde edilen değer } \\
\text { mukayesesi. } \\
\text {-Ürün farklılaştırma (Baltacioğlu ve } \\
\text { Kaplan, 2007: 51). } \\
\text {-Algilanan gida güvenliği riski ve } \\
\text { yüksek fiyat (Williams vd., 2000). }\end{array}$ \\
\hline $\begin{array}{l}\text { Tutundurma } \\
\text { (Promotion) }\end{array}$ & $\begin{array}{l}\text {-Hedef kitle işletme ve ürünleri } \\
\text { hakkında ne kadar bilgi sahibi } \\
\text { (Sümer ve Eser, 2006: 168). } \\
\text {-Kolay anlaşılan fayda iletişimi ve } \\
\text { kaliteli promosyonlar (Bennett, } \\
\text { 1997: 155). } \\
\text {-İnsanlar promosyon hediyelerine } \\
\text { daha fazla tepki verip (ücretsiz } \\
\text { hediyeler vb.) daha dürtüsel satın } \\
\text { almaktadır (Youn ve Faber, 2000). }\end{array}$ & $\begin{array}{l}\text {-Evrenselcilik (Aertsens vd., 2009b). } \\
\text {-Etik bağlılık (Santhi vd., 2007) } \\
\text {-Risk algılamas1 / bilgilendirme } \\
\text { (Magkos vd., 2006). } \\
\text {-Ekoloji ve çevrecilik bilgisi (Kacur, } \\
\text { 2009: 253). } \\
\text {-Algilanan değer (Essoussi ve Zahaf, } \\
\text { 2008: 96). } \\
\text {-Dijitalleşme (Constantinides, 2006) }\end{array}$ \\
\hline $\begin{array}{c}\text { Dağıtım } \\
\text { (Place) }\end{array}$ & $\begin{array}{l}\text {-Optimum üretim hattı, } \\
\text { operasyonel taleplerin karşılanması } \\
\text { ve müşterinin ihtiyacına hızlı } \\
\text { cevap verme (Bennett, 1997: 155). } \\
\text {-Perakende pazarlama karmas1 } \\
\text { içinde “lojistik konsepti”; yer, } \\
\text { fiziksel dağıtım ve personel } \\
\text { karması. } \\
\text { "Ticari konspet”; ürün, sunum, } \\
\text { fiyat ve promosyon karması (Ster } \\
\text { van der, 1993). } \\
\text {-Web perakendeciliği: veri tabanı } \\
\text { (database), etkileşim (interaction) } \\
\text { ve ağ (network) (Wang vd., 2000). }\end{array}$ & $\begin{array}{l}\text {-Perakende zincirleri ve organik ürün } \\
\text { mağazaları (Kurt, 2006: 27). } \\
\text {-Depolama (Yanmaz, 2011: 11). } \\
\text {-Mikro pazarlama (Klonsky, 2000). } \\
\text {-Güven (Padel ve Foster, 2005: 621). }\end{array}$ \\
\hline
\end{tabular}

"Ürün" elemanında yaşam kalitesi ve sağlık, ikna olma (inandırıcılık) ile organik etiketleme yoluyla değer güvenliği sağlama kavramları önemli olup, "Fiyat" da tüketicinin 
bilişsel yapılarına tesir ederek satın alma davranışına etki edebilecek kalite kavramı ön plana çıkmaktadır. "Tutundurma” elemanında sağlık ve beslenme faydaları kavramı merkeze otururken, "tutundurma" faaliyetlerinin alt boyutlarında; tüketici demografisi noktasında evrenselcilik (duyarlılık, temiz çevre), psikografik ve davranışsal bölümlendirme de değerler, risk algılaması, bilgilendirme, güven ve ben-merkezcilik kavramları, örgütlerin ilgili karma elemanları noktasında göz önüne alması gereken kavramlar olarak karşımıza çıkmaktadır. Son olarak "dağıtım" elemanında erişebilirlik, istikrar (ürün kalitesinde) ve yine güven (özellikle ihracat alt boyutunda) kavramları karşımıza çıkmaktadır. Ayrıca anlayış, tolerans, insanın ve doğanın refahını koruma şeklinde özetleyerek tanımlayabileceğimiz "evrenselcilik" kavramı, örgütlerin bütün 4P elemanları içerisinde kullanabileceği bir kavram olarak da değerlendirilebilir.

Gelecekte yapılacak araştırmalarda, bireysel ve toplulukçu kültürlerin organik gıda alımı noktasında önem atfettiği kavramların farklılaşıp farklılaşmadığı hususları nitel yöntem vasıtası ile derinlemesine araştırılabilir. Zira planlı davranış teorisi, hissedilen sosyal baskı derecesinin satın alma davranışına etki ettiğini ileri sürmektedir.

\section{KAYNAKÇA}

Aertsens, J., Mondelaers, K., \& Huylenbroeck, G.V. (2009a). Differences in Retail Strategies on The Emerging Organic Market. British Food Journal, 111(2), 138-154.

Aertsens, J., Verbeke, W., Mondelaers, K., \& Huylenbroeck, G.V. (2009b). Personal Determinants of Organic Food Consumption: A Review. British Food Journal, 111(10), $1140-1167$.

Aksoy, U. (2001). Dünya'da ve Türkiye'de Ekolojik Tarım. Türkiye 1. Ekolojik Tarım Sempozyumu. Tibyan Yayıncılık. İzmir.

Aksoy, U. (2003). Dünya'da Organik Tarım, Organik Tarım Üretim Pazarlama Sertifikasyon Ĕgitim Semineri ve Paneli, Gaziantep.

Albayrak, M., \& Dölekoğlu, C. (2006). Gıda Perakendeciliğinde Market Markalı Ürün Stratejisi. Akdeniz I.I.I.B.F. Dergisi, 11(6), 204-218.

Altındişli, A. \& İlter, E. (2002). Ekolojik Tarımda İlke ve Kavramlar. Organik Tarım. Emre Basımevi. İzmir.

Altıntaş, M. H. (2000). Tüketici Davranışları; Müşteri Tatmininden Müşteri Değerine. Alfa Yayınları: Bursa.

Anderson, L. \& Taylor, R. L. (1995). Mc Carthy’s 4PS: Timeworn or Time Tested. Journal of Marketing Theory \& Practice, 3(3), 1-9.

Anselmsson, J., Bondesson, V. N., \& Johansson, U. (2014). Brand Image and Customers Willingness to Pay a Price Premium for Food Brands, Journal of Product \& Brand Management. 23(2), 90-102.

Araslı, Z.S. \& Esen, A. (2008). Organik Tarım Sektörü. Türkiye Kalkınma Bankası A.Ş, Teknoloji İzleme ve Araştırma Müdürlüğ̈̈ Yayını, Ankara, 1-100.

Ataseven, Y. \& Güneş, E. (2008). Türkiye'de İşlenmiş Organik Tarım Ürünleri Üretimi ve Ticaretindeki Gelişmeler. Uludağ Üniversitesi Ziraat Fakültesi Dergisi, 22(2), 25-33.

Ayan, R. \& Bayturan, N. (2002). Ekolojik Tarımda Kontrol- Sertifikasyon Sistemi ve Karşılaşılan Sorunlar. Organik Tarım. Emre Basımevi. İzmir.

Aytoğu, R.K. (2006). Organik Tarım Analizi ve AB pazarı firsatı. İstanbul Ticaret Odası Yayınları, İstanbul.

Babacan, M. (1998). Pazarlama İletişimi: Kavramsal Bir İredeleme. Pazarlama Dünyası Dergisi, 71(12), 4-7. 
Bagozzi, R., Baumgartner, H., \& Yi, Y. (1989). An Investigation Into The Role of Intentions as Mediators of The Attitude-Behavior Relationship. Journal of Economic Psychology, 10, 35-62.

Baltacioğlu, T. \& Kaplan, M. D. (2007). İyi İletişim=İyi Pazarlama: Tüketiciyle Doğru İletişim Kurma Yöntemleri. Mediacat Yayınlart: İstanbul.

Batte, M. T., Hooker, N. H., Haab, T. C., \& Beaverson, J. (2007). Putting Their Money Where Their Mouths Are: Consumer Willingness to Pay For Multi-Ingredient, Processed Organic Food Products. Food Policy, 32, 145-159.

Bell, R., \& Meiselman, H. (1995). The Role of Eating Environments in Determining Food Choice. İçinde; D. W. Marshall (der.), Food choice and the consumer (292-310). London: Chapman and Hall.

Bennett, A. R. (1997). The Five Vs-A Buyer's Perspective of The Marketing Mix. Marketing Intelligence and Planning, 15 (3): 151:155.

Biemans-Żakowska, S. (2011). Polish Consumer Food Choices and Beliefs About Organic Food. British Food Journal, 113(1), 122-137.

Blut, M., Teller, C., \& Floh, A. (2018). Testing Retail Marketing-Mix Effects on Patronage: A Meta-Analysis, Journal of Retailing, 94(2), 113-135.

Brunso, K., Scholderer, J., \& Grunert, K. G. (2004), Closing The Gap Between Values and Behavior - A Means-End Theory of Lifestyle, International Research Seminar on Marketing Communications and Consumer Behavior, La Londe. Elsevier Science, Amsterdam.

Canarslan, N.Ö., \& Uz, C.Y. (2019). Annelerin ve Hamilelerin Organik Gida Satın Alma Davranışları. Gaziantep Üniversitesi Sosyal Bilimler Dergisi, 18(1), 457-478.

Capon, N., \& Hulbert, J. M. (2000). Marketing in The 21st Century, Pearson Education.

Chen, M. F. (2007), Consumer Attitudes and Purchase Intentions in Relation to Organic Foods in Taiwan: Moderating Effects of Food-Related Personality Traits. Food Quality and Preference, 18(7), 1008-21.

Chryssides, G. D., \& Kaler, J. H. (1993). An Introduction to Business Ethics. Chapman \& Hall, London: UK.

Constantinides, E. (2006). The Marketing Mix Revisited: Towards The 21st Century Marketing. Journal of Marketing Management, 22, 407-438.

Çelik, Y. \& Bilgiç, A. (2003). Dünyada ve Türkiye'de Organik Tarımın Mevcut Durumu ve Gelişimi. Türk-Koop Dergisi, 25.

Dalkıran, G. B. (2009). Türkiye'de Ekolojik Ürünlerin Pazarlama Süreci ve Turizm Boyutu. Yayınlanmış Doktora Tezi. Fen Bilimleri Enstitüsü, Tarım Ekonomisi Ana Bilim Dalı. Namık Kemal Üniversitesi.

Defrancesco, E. \& Rossetto, L. (2007). From Niche to Market: The Growth of Organic Business in Italy. Organic Food Springer, New York: 3-16.

Demirer, F. Ç. (2002). Ekolojik Tarım Üretiminin Türkiye'deki Gelişim Sürecinin İşletmeler Bazında İncelenmesi ve İhracat Performanslarının Değerlendirilmesi. Yayınlanmamış Yüksek Lisans Tezi. Dokuz Eylül Üniversitesi. İzmir.

Eertmans, A., Baeyens, F., \& Van den Bergh, O. (2001). Food Likes and Their Relative Importance in Human Eating Behavior: Review and Preliminary Suggestions for Health Promotion. Health Education Research, 16, 443-456.

Eker, Ö. (2006). Lojistik Yönetimi ve Tedarik Lojistiği Sürecinde Performansın Arttırılması. Yüksek Lisans Tezi, İstanbul Teknik Üniversitesi Fen Bilimleri Enstitüsü.

Ersun, N., \& Arslan, K. (2010). Türkiye'de Organik Tarım ve İyi Tarım Uygulamaları. Yurtiçi Sektörel Etütler ve Araştırmalar. İstanbul Ticaret Odası. İstanbul. 
Eti, H.S. (2014). Organik Gıdaların Pazarlanması ve Organik Gıdalara Karşı Tüketici Tutum ve Davranışları Analizi. Yüksek Lisans Tezi. Namık Kemal Üniversitesi Fen Bilimleri Enstitüsü.

Fotopoulus, C., \& Krystallis, A. (2002). Organic Product Avoidance: Reasons for Rejection and Potential Buyers' Identification In a Countrywide Survey. British Food Journal, 104(3-5), 233-260.

Furst, T., Connors, M., \& Bisogni, C. A. (1996). Food Choice: A Conceptual Model of The Process. Appetite, 26, 247-265.

Gad Mohsen, M. \& Dacko, S. (2013). An Extension of The Benefit Segmentation Base for The Consumption of Organic Foods: A Time Perspective. Journal of Marketing Management. 29(15-16), 1701-1728.

Gil, J. M. (2000). Market Segmentation and Willingness To Pay For Organic Products in Spain. International Food and Agribusiness Management Review, 3,207-226.

Goldsmith, R. E., Frieden, J., \& Henderson, K. V. (1997). The Impact of Social Values on Food-Related Attitudes. British Food Journal, 99(9), 352-7.

Gracia, A. \& Magistris, T. (2007). Organic Food Product Purchase Behaviour: A Pilot Study for Urban Consumers in The South of Italy, Spanish Journal of Agricultural Research, 5 (4): 439-451.

Grimmer, M., Kilburn, A.P., \& Miles, M.P. (2015). The Effect of Purchase Situation on Realized Rro-Environmental Consumer Behavior. Journal of Business Res. http://dx.doi.org/10.1016/j. jbusres.

Gündüz, A. Y. \& Kaya, M. (2007). Avrupa Birliği Tarım Politikası ve Türkiye'de Organik Tarımın Geliştirilmesi Üzerine Olası Etkisi. Elektronik Sosyal Bilimler Dergisi, 6(21).

Güzel, H. T. (2001). Dünya’da ve Türkiye’de Ekolojik Tarım Ürünleri Üretimi ve İhracatı Geliştirme Olanakları. ITO Yayınlart: 2001-14. İstanbul.

Hadjali, H. R., Salimi, M., \& Nazari, M. (2008). Exploring Main Factors Affecting on Impulse Buying Behaviors. Journal of American Science, 8(1), 245-251.

Hartman, N. H. (1997). The Evolving Organic Marketplace. Hartman and New Hope Industry Series Report. Washington, D.C.

Heaton, S. (2001). Organic Farming, Food Quality and Human Health: A Review of the Evidence. Bristol: Soil Association.

Hill, H. \& Lynchehaun, F. (2002). Organic Milk: Attitudes and Consumption Patterns. British Food Journal. 104(7), 526-542.

Hughner, R.S., Mcdonagh, P., Prothero, A., Shultz, C.J. II \& Stanton, J. (2007). Who Are Organic Food Consumers?: A Compilation and Review of Why People Purchase Organic Food?. Journal of Consumer Behaviour, 6, 1-17.

Johnston, J. (2008). The Citizen-Consumer Hybrid: Ideological Tensions and The Case of Whole Foods Market”. Theory and Society, 37(3), 29-70.

Kacur, L. L. (2009). Erciyes Üniversitesi İİBF Akademik ve İdari Personeli ile İIBF İşletme Gündüz ve İkinci Öğretim Öğrencilerinin Organik Ürünleri Algılamaları. Erciyes Üniversitesi Íktisadi ve İdari Bilimler Fakültesi Dergisi, 33(7-8), 249-277.

Kenanoğlu, Z. \& Karahan, Ö. (2002). Policy Implementations for Organic Agriculture in Turkey. British Food Journal, 104(3/4/5), 300-318.

Kılıç, S., Duman, O., \& Bektaş, E. (2014). Organik Ürünlerin Pazarlama Stratejileri ve Üreticiler Üzerinde Bir Alan Araştırması. Business and Economics Research Journal, 5(1), 39-65.

Kırımhan, S. (2005). Organik tarım sistemleri ve çevre, (1.bask1). Turhan Kitapevi: Ankara.

Klonsky, K. (2000). Forces Impacting The Production of Organic Foods. Agriculture and Human Values, 17, 233-243. 
Knudson, W. A. (2007). “The Organic Food Market”. The strategic marketing institute working paper, Michigan State University.

Koç, D. S (2009). Organik Tarım Ürünleri Dış Pazar Araştırması. Dış Ticaret Müsteşarlı̆̆ İhracatı Geliştirme Etüt Merkezi, Ankara.

Kurt, Z. (2006). Organik Tarım Ürünleri Pazarlaması ve Uygulamalar. Yüksek Lisans Tezi, Dokuz Eylül Üniversitesi Sosyal Bilimler Enstitüsü, İzmir.

Lamb, C. G. (1994). The Organic Food Market: A Discussion of Potential and Problems. Department of Economics and Marketing Discussion Paper, Lincoln University: Canterbury.

Magistris, T. \& Gracia, A. (2008). The Decision to Buy Organic Foods in Southern Italy. British Food Journal. 110(9), 929-947.

Magkos, F., Arvaniti, F., \& Zampelas, A. (2006). Organic Food: Buying More Safety or Just Peace of Mind? A Critical Review of the Literature. Critical Reviews in Food Science and Nutrition, 46(1), 23-56.

Makatouni, A. (2002). What Motivates Consumers to Buy Organic Food in the UK? Results From a Qualitative Study”. British Food Journal, 104(3/4/5), 345-352.

Marangoz, M. (2008). Organik Ürünlerinin Pazarlanması, Ekin Kitabevi: Bursa.

McEachern, M. G. \& McClean, P. (2002). Organic Purchasing Motivations and Attitudes: Are They Ethical?. International Journal of Consumer Studies, 26(2), 85-92.

Mintel, (2000). Organic Food and Drink Retailing, Market Intelligence Unit of the UK Economic Intelligence Unit, London.

Mutlu, H. M. (2008). Dağıtım Kanallarında Bağımlılık ve Özgün Yatırımların Güven Üzerine Etkileri. 13. Ulusal Pazarlama Kongresi (2008), Pazarlamada Yeni Yaklaşımlar Bildiriler Kitab1, 151-160.

Nasır, A. \& Kımıloğlu, H. (2006). Organik Tarım Ürünlerinin Ekonomik Boyutu ve Pazarlaması. Rekabet Avantajı Elde Etmede Organik Tarım Sektörü Sektörel Stratejiler ve Uygulamalar, Urak Yayını.

Padel, S. \& Foster, C. (2005). Exploring The Gap Between Attitudes and Behaviour. Understanding Why Consumers Buy or Do Not Buy Organic Food. British Food Journal, 107(8), 606-625.

Park, T. A. (2009). Assessing The Returns From Organic Marketing Channels. Journal of Agricultural and Resource Economics, 34(3), 483-497.

Paul, J. \& Rana. J. (2012). Consumer Behavior and Purchase Intention for Organic Food. Journal of Consumer Marketing, 29(6), 412-422.

Pettie, K. (1992). Green Marketing. Pitman Publishing, London: UK.

Pino, G., Peluso, A.M., \& Guido, G., (2012). Determinants of Regular and Occasional Consumers Intentions to Buy Organic Food. Journal of Consumer Affairs, 46, 157-169.

Rana, J. \& Paul, J. (2017). Consumer Behavior and Purchase Intention for Organic Food: A Review and Research Agenda. Journal of Retailing and Consumer Service, (38), 157165.

Roddy, G., Cowan, C., \& Hutchinson, G. (1994). Organic Food: A Description of Irish Market. British Food Journal, 96(4), 3-10.

Rodriguez, E., Lacaze, V., \& Lupin, B. (2008). Valuation of Consumers' Willingness-to-Pay for Organic Food in Argentina”. 12th Congress of the European Association of Agricultural Economists - EAAE, Ghent.

Rokeach, M. J. (1973). The Nature of Human Values, The Free Press, New York, NY.

Saba, A. \& Messina, F. (2003). Attitudes Towards Organic Foods and Risk/Benefit Perception Associated With Pesticides, Food Quality and Preference, 14, 637-45. 
Santhi, P., Jerinabi, U., \& Gandhi, N. M., (2007). Green Consumerism-Issues and Implications. Indian Journal of Marketing, 37(1).

Sarıkaya, N. (2007). Organik Ürün Tüketimini Etkileyen Faktörler ve Tutumlar Üzerine Bir Saha Çalışması, Kocaeli Üniversitesi Sosyal Bilimler Enstitüsü Dergisi, 14(2), 110-125.

Shafie, F. A. \& Rennie, D. (2012). Consumer Perceptions Towards Organic Food. Procedia Social and Behavioral Sciences, 49, 360-367.

Shamsollahi, A., Chong, C. W., \& Nahid, N. (2013). Factors Influencing on Purchasing Behaviour of Organic Foods. Human Social Science Research, 1(2), 93-104.

Singh, A., \& Verma, P. (2017). Factors Influencing Indian Consumers Actual Buying Behaviour Towards Organic Food Products. Journal of Cleaner Production, 167, 473483.

Smith, A. (2017). Ulusların Zenginliği. (M. Saltoğlu, Çev.) Ankara: Palme Yayınevi. (1776).

Soler, F., Jose, M. G., \& Sanchez, M. (2002). Consumers Acceptability of Organic Food in Spain. British Food Journal, 104(8), 670-687.

Sondhi. N. \& Vani, V. (2007). An Empirical Analysis of The Organic Retail Market in the NCR, Global Business Review, 8(2), 283-302.

Ster, van der W. (1993). Marketing En Detailhandel. Marketing and Retailing, Groningen, The Netherlands: Wolters-Noordhoff, 328.

Stobbelaar, D.J., Casimir, G., Borghuis, J., Marks, I., Meijer, L., \& Zebeda, S. (2007). Adolescents Attitudes Towards Organic Food: A Survey of 15- to 16-Year Old School Children, International Journal of Consumer Studies, 31: 349-56.

Subaşı, E. (2005). Uluslararası Pazarlara Açılmada Farklı Kültürlerin Etkileri. IGEME. Ankara.

Sümer, S. I. \& Eser, Z. (2006). Pazarlama Karması Elemanlarının Evrimi. Gazi Üniversitesi İktisadi ve İdari Bilimler Fakültesi Dergisi, 8(1), 165-186.

Thøgersen, J. (2002). Direct Experience and The Strength of The Personal Norm-Behavior Relationship. Psychology \& Marketing, 19(10), 881-93.

Thøgersen, J. (2007). Consumer Decision Making With Regard to Organic Food Products, Vaz, M.T.D.N., Vaz, P., Nijkamp, P. ve Rastoin, J. L. (Der.), Traditional Food Production Facing Sustainability. A European Challenge, Ashgate, Farnham.

Tirkeş, Ç (2008). Yeşil Pazarlama: Türkiye'de Organik Gıda Ürünlerinin Kullanımını Arttırmaya Yönelik Stratejiler. Yayımlanmamış Doktora Tezi.

TNS (2004), Organic Food: Understanding The Consumer and Increasing Sales, Result of a 2003 Taylor Nelson Sofres Survey Published Jointly by The Soil Association, Welsh Agri-Food Partnership. Organic Centre Wales and the Welsh Development Agency, Aberystwyth.

Usal, G. (2006). Toros Dăg Köylerinde Organik Tarım Yoluyla Üretici Gelirlerini Arttırma Olanakları. Yayımlanmamış Doktora Tezi, Çukurova Üniversitesi Fen Bilimleri Enstitüsü. Adana.

Via, G.L. \& Nucifora, A. M. D. (2002). The Determinants of The Price Mark-Up for Organic Fruit and Vegetable Products in The European Union. British Food Journal, 104(3/4/5), 319-336.

Wang, F., Head, M., \& Archer, N. (2000). A Relationship-Building Model for The Web Retail Marketplace. Internet Research: Electronic Networking.

Williams, P. R. D. \& Hammitt, J. K. (2000). A Comparison of Organic and Conventional Fresh Produce Buyers in the Boston Area. Risk Analysis, 20(5), 735-746.

Yanmaz, R. (2011). Organik Ürünlerin Pazarlanması ve Ticareti. http://www.agri.ankara.edu.tr/ bahce/1097_1183723867.doc

Youn S. \& Faber, R. J. (2000). Impulse Buying: Its Relation to Personality Traits and Cues. Advances in Consumer Research, 27, 179-185. 
Yurdakul, O. (2004). Tarım Ürünleri Pazarlaması. Çukurova Üniversitesi Ziraat Fakültesi Ofset Atölyesi, Adana.

Zanoli, R. \& Naspetti, S. (2002). Consumer Motivation in The Purchasing of Organic Food, A Means-End Approach. British Food Journal, 104(8), 643-653. 